\section{Earthwatch Institute}

1380 Soldiers Field Rd., Suite 2700, Boston, MA 02135, United States of America.

Tel: $\quad$ (1) 8007760188

Email: info@earthwatch.org

Website: earthwatch.org/

Since its founding in 1971, Earthwatch has been taking action to address global change through a time-tested model of citizen science and community engagement. By pairing citizen science volunteers from all sectors of society with researchers around the world, Earthwatch teams have helped to safeguard critical habitats, conserve biodiversity, and promote the sustainable use of natural resources.

\section{Earthwatch Field Research Grants}

Purpose: Earthwatch funds field-based scientific research that is rigorous, relevant, and impactful. Earthwatch-funded projects conduct research around the globe. All research must incorporate citizen-scientist participation in data collection. Citizen-scientist participants are recruited by Earthwatch. Requests for pre-proposals are distributed annually. Pre-proposals must be submitted by the PI. All PIs must have a PhD and an affiliation with a university, government agency, or science-focused NGO.

Eligibility: All proposals must be submitted by the Principal Investigator (PI). All PIs must have a PhD and an affiliation with a university, government agency, or NGO

Level of Study: Doctorate, Postdoctorate, Postgraduate, Research

Type: Grant

Value: US\$20,000-80,000 annually

Length of Study: Successful proposals are funded for 3 years, subject to passing an annual performance review

(C) Springer Nature Limited 2021

Palgrave Macmillan (ed.), The Grants Register 2022,

https://doi.org/10.1057/978-1-349-96042-2
Frequency: Annual

Study Establishment: Research sites

Country of Study: Any country

Application Procedure: Requests for proposals are distributed in the spring. Applicants must submit a pre-proposal for consideration. Please see the Earthwatch website (earthwatch. org) for more information

Closing Date: 31 December

Funding: Corporation, Foundation, Private

Contributor: Volunteers' contributions

Additional Information: For additional project requirements and information: earthwatch.org/research-funding www. archaeological.org/grant/field-research-grants/

\section{Ècole Normale Supérieure (ENS)}

Tel:

Email:_ens-international@ens.fr

Website: www.ens.fr/admission/selection-internationale/? lang $=$ en

Ècole Normale Supérieure (ENS) allows the most promising international students, either in Science or in Arts \& Humanities, to follow a three-year Masters Degree at the University.

\section{Ėcole Normale Supérieure International Selection Scholarships}

Level of Study: Postgraduate

Type: Scholarship

Value: monthly grant of $€ 1,000$ for 3 years and accomodation facility provided

Length of Study: 3 years

Frequency: Annual 
Country of Study: France

Application Procedure: You must fill and validate the initial application form which will be available at the official website when the application opens. Within 2 days, you will receive an email to activate an account on Dematec, an application platform where you must upload the required documents

Closing Date: 31 October

Contributor: Ècole Normale Supérieure in Paris, France

Additional Information: For more details, please visit official scholarship website: greatyop.com/ens-internationalselection-scholarship/

\section{For further information contact:}

Email: ens-international@ens.fr

\section{École Normale Supérieure de Lyon}

15 parvis René Descartes, BP 7000, F-69342 Lyon Cedex 07, France.

Tel: $\quad$ (33) 437376000

Website: www.ens-lyon.fr/en/

Contact: ENS de Lyon

The École Normale Supérieure de Lyon is an elite French public institution that trains professors, researchers, senior civil servants as well as business and political leaders. Students choose their courses and split their time between training and research in sciences and humanities. Built on the tradition of the ENS de Fontenay-Saint-Cloud, founded in 1880, the ENS de Lyon also focuses on educational research. It is a symbol of French Republican meritocracy and it remains committed today to disseminating knowledge to the widest audience and to promoting equal opportunity.

\section{Ampère \& MILYON Excellence Scholarships for International Students}

Purpose: The ENS de Lyon and its partners offer scholarships for excellent international students to enrol in its Masters programs in the Exact Sciences, the Arts, and Human and Social Sciences

Eligibility: Priority to students coming from abroad. Candidate for admission in Masters Year 1: provide proof that you have obtained a Licence (equivalent to 180 ECTS European credits) or an equivalent diploma/level. Candidate for admission in Masters Year 2: provide proof that you have successfully reached Masters Year 1 level (equivalent to
240 ECTS European credits) or have attained an equivalent diploma/level

Level of Study: Graduate

Type: Scholarship

Value: $€ 1,000$ per month or in addition to another scholarship to reach a maximum of $1000 € /$ month (e.g. a bursary of the French Embassy in Chile)

Length of Study: 1-2 years

Frequency: Annual

Study Establishment: Masters program in Advanced Mathematics, Masters in Fundamental Computer Science

Country of Study: France

Application Procedure: Complete and submit the online application form.

Closing Date: 8 January

Funding: Government, Private

Additional Information: Please note : before beginning your application, read carefully all information and documents requested, and choose your Master's program www.enslyon.fr/en/studies/academic-programs/bachelor-masters/bios ciences-and-modeling-complex-systems. www.ens-lyon.fr/ en/studies/admissions/application-masters-degrees-scholarships

\section{For further information contact:}

Email: ampere.scholarship@ens-lyon.fr

\section{Ampère Excellence Scholarships for International Students}

Purpose: The Ampère Scholarships of Excellence offer scholarships for excellent international students with the opportunity to pursue one of the eligible Masters programs offered at ENS de Lyon

Eligibility: You must be a foreign national. Born after January, 1st, 1995 (26 years maximum). Candidate for admission in Masters Year 1: provide proof that you have obtained a Licence (equivalent to 180 ECTS European credits) or an equivalent diploma/level. Candidate for admission in Masters Year 2: provide proof that you have successfully reached Masters Year 1 level (equivalent to 240 ECTS European credits) or have attained an equivalent diploma/level.

Level of Study: Masters Degree

Type: Scholarship

Value: $1,000 €$ a month during one or two academic years

Frequency: As available

Country of Study: France

Application Procedure: Complete and submit the online application form.

No. of awards offered: 20

Closing Date: 8 January 
Additional Information: For more details, please visit official scholarship website: www.ens-lyon.fr/en/studies/admis sions/application-masters-degrees-scholarships

\section{For further information contact:}

Email: ampere.scholarship@ens-lyon.fr

\section{École Normale Supérieure Paris-Saclay}

61, avenue du Président Wilson, F-94235 Cachan Cedex, France.

Tel: (33) 147402000

Email: communication@ens-paris-saclay.fr Website: ens-paris-saclay.fr/en

ENS Paris-Saclay is a training and research centre with an international and multidisciplinary outlook. It offers students an early immersive contact with research and mobilises the laboratories in their training in basic sciences, humanities and social sciences, and engineering sciences.

\section{Monabiphot Masters Scholarships}

Purpose: This masters course offers an original qualification in the highly innovative domain of molecular photonics for telecommunications and biology. Skills will be acquired at the strongly interdisciplinary level needed to master emerging technologies and to develop original concepts and applications aiming at novel technological breakthroughs in this domain Eligibility: Both European Union students and Non-European Union students are eligible to apply

Level of Study: Postgraduate

Type: Scholarship

Value: Non-European Union students $€ 23,500$ per year, European Union students $€ 16,000$ per year, Additional scholarships for specific regions $€ 47.000$

Country of Study: France

Closing Date: 31 January

Additional Information: www.scholarshipsads.com/monab iphot-masters-scholarships-international-students-france-2017/

\section{For further information contact:}

LPQM ENS-Cachan, 61, Avenue du President Wilson, F-94235 Cachan Cedex, France.

Tel: (33) 147405560

Email:1edoux@lpqm.ens-cachan.fr

\section{Ecole Polytechnique Federale de Lausanne}

EPFL SB B2F-LAB, PH H1 446 (Bâtiment PH), Station 3, CH-1015 Lausanne, Switzerland.

Tel: $\quad$ (41) 216931111

Website: www.epfl.ch/en/

EPFL is Europe's most cosmopolitan technical university. It welcomes students, professors and collaborators of more than 120 nationalities. EPFL has both a Swiss and international vocation and focuses on three missions: teaching, research and innovation. EPFL collaborates with an important network of partners, including other universities and colleges, secondary schools and gymnasiums, industry and the economy, political circles and the general public, with the aim of having a real impact on society.

\section{Excellence Fellowships}

Purpose: EPFL offers a limited number of fellowships at the Master's level to students with outstanding academic records. Some of the fellowships are financed by EPFL directly and others through partnerships with foundations or companies.

Eligibility: Anyone applying to an EPFL master's program is eligible. EPFL grants a limited number of fellowships to the most deserving candidates based solely on their academic records.

Level of Study: Masters Degree

Type: Scholarships

Value: For external applicants, 1. CHF 8,000 per semester (CHF 32,000 for a 2-year degree - 120 credits or CHF 24,000 for a 1.5-year degree - 90 credits). 2. Reservation of an accommodation (student room in a student residence) and for internal applicants (after EPFL bachelor's degree), CHF 5,000 per year (CHF 10,000 for a master)

Country of Study: Switzerland

Application Procedure: For EXTERNAL applications: Candidates should apply via the same online form than their application to a master's program by April 15 or December 15. Please note that it is necessary to tick a box indicating that the candidates profile should also be considered for an excellence fellowship. For INTERNAL applications (after EPFL bachelor's degree): Sections might contact students to ask if they want to submit an application for an excellence fellowship. Students can also submit an application to their section by April 30. The application should contain: 1. a CV. 2. a motivation letter. 3. a transcript of all grades earned at EPFL. 4. a recommendation letter from the sections' director. 
Closing Date: 15 April

Additional Information: If the master at EPFL is a second master's degree, candidates are not eligible for an excellence fellowship. www.epfl.ch/education/studies/en/financing-study/ grants/excellence-fellowships/

\section{For further information contact:}

Email:_e-fellowship@epfl.ch; student.services@epfl.ch

\section{Economic History Association (EHA)}

Economic History Association, Department of Economics, University of Wisconsin-La Crosse, 1725 State St., La Crosse, WI 54601, United States of America.

Tel: $\quad$ (1) 6087856863

Email: mhaupert@uwlax.edu

Website: eh.net/eha/

Contact: Michael Haupert, Executive Director

The Economic History Association was founded in 1940. Its purpose is to encourage and promote teaching, research, and publication on every phase of economic history, broadly defined, and to encourage and assist in the preservation and administration of the materials for research in economic history.

\section{Annual Meetings Travel and Hotel Subsidies}

Purpose: Intended for disseminating preliminary results from graduate thesis work.

Eligibility: Who have presented a poster are eligible for the dissertation session in a subsequent year, but may present a poster session only once during their graduate career. If a student applies both for the dissertation session and to present a poster, and the student is accepted to be part of the dissertation session, a prior invitation to present a poster that year will be withdrawn. Participating in the poster session does not preclude submitting a paper and having it accepted for the regular program the following year. Applicants must be members of the Association.

Level of Study: Postdoctorate

Type: Travel grant

Value: 1. Up to US\$500 for domestic flights or train fare, up to US\$800 for international flights. 2. Complimentary hotel rooms for up to 3 nights. 3 . 60 percent discount on the registration fee.
Application Procedure: Applicants will need to provide a 250 word abstract, a current $\mathrm{CV}$, and request a letter of support from their dissertation advisor.

Closing Date: 20 May

Additional Information: Questions about the poster session should be directed to Professor Eric Hilt (ehilt@wellesley. edu) or Professor Howard Bodenhorn (bodnhrn@clemson. edu) co-chairs of the program committee. eh.net/eha/grantsand-fellowships/

\section{For further information contact:}

Email: ckitchens@fsu.edu

\section{Arthur H Cole Grants-in-Aid}

Purpose: The Committee on Research in Economic History awards Arthur H. Cole grants-in-aid to support research in economic history, regardless of time period or geographic area.

Eligibility: Applicants must be members of the Association and must hold the Ph.D. degree.

Type: Grant

Value: Up to US $\$ 5,000$

Frequency: As available

Country of Study: Any country

Application Procedure: Apply online: eh.net/eha/colegrant-application/

Closing Date: 1 March

Funding: Private

Additional Information: Membership enquiries should be addressed to the office of the Executive Director or the website eh.net/eha/grants-and-fellowships/

\section{For further information contact:}

Professor Carl Kitchen, Committee on Research in Economic History.

Email: ckitchens@fsu.edu

\section{Edinburgh Napier University}

Sighthill Campus, Sighthill Court, Edinburgh EH11 4BN, United Kingdom.

Tel: (44) 3339006040

Email: studentrecruitment@napier.ac.uk

Website: www.napier.ac.uk/

Contact: Edinburgh Napier University 
Edinburgh Napier University is a public university in Edinburgh, Scotland. Napier Technical College, the predecessor of the university was founded in 1964, taking its name from Scottish mathematician John Napier.

\section{African Scholarships}

Purpose: The University has partial scholarships for selffunding students from Africa.

Eligibility: You must be: 1. domiciled in Africa at the time of application. 2. self-funding your course. 3 . holding an offer to study a masters course

Level of Study: Masters Degree

Type: Scholarship

Value: $£ 2,000$

Country of Study: United Kingdom

Application Procedure: The number of scholarships is limited and they are offered on a first-come, first-served basis. 1. You meet the eligibility criteria detailed above. 2 . You have made your $£ 3,500$ deposit payment towards your fees.

Additional Information: Students studying full-time courses lasting longer than 12 months are not eligible for this award. You are not eligible if you have discounted tuition fees from a partner university or are in receipt of another scholarship. www.napier.ac.uk/study-with-us/bursaries/african-scholarships

\section{For further information contact:}

Buchi Chinwuba, Regional Recruitment Officer.

Tel: (44) 8166782704

Email: O.Chinwuba@napier.ac.uk

\section{ASEAN Scholarship}

Purpose: The University has partial scholarships for selffunding students from South East Asia.

Eligibility: You must be: 1. Domiciled in Cambodia, Indonesia, Laos, Malaysia, Myanmar, Philippines, Singapore, Thailand, Brunei or Vietnam. 2. Be self-funding your course. 3. Holding an offer to study a full-time masters course

Level of Study: Postgraduate

Type: Scholarship

Country of Study: United Kingdom

Application Procedure: The scholarships will be awarded on a first-come, first-served basis. 1. You hold an unconditional offer to study a full-time postgraduate course at Edinburgh Napier. 2. You meet the eligibility criteria above. 3. You have made your $£ 3,500$ deposit payment towards your fees.

Additional Information: If you have discounted tuition fees from a partner university, you are not eligible for this scholarship. www.napier.ac.uk/study-with-us/bursaries/ asean-scholarship

\section{For further information contact:}

Subra Singaram.

Tel: (60) 125790105

\section{Brazil Scholarship}

Purpose: The University has partial scholarships for selffunding students from Brazil.

Eligibility: 1. be living in Brazil at the time of application. 2 . be self-funding your course. 3 . be holding an unconditional offer to study a masters course. 4 . have made your $£ 3,500$ deposit payment toward your fees.

Level of Study: Postgraduate

Type: Scholarship

Value: $£ 4,000$

Country of Study: United Kingdom

Application Procedure: The scholarships will be awarded on a first-come, first-served basis when you meet the eligibility criteria.

Additional Information: If you have discounted tuition fees from a partner university, you are not eligible for this scholarship. You do not have to hold an unconditional offer and have paid the deposit in order to apply. www.napier.ac.uk/ study-with-us/bursaries/brazil-scholarship

\section{For further information contact:}

Rua Dr. Cesário Mota Junior, 369, Conj 52, B-01221020 São Paulo, Brazil.

Tel: (44) 1139570488

Email: contato@loveuk.com.br; f.giuntoli@napier.ac.uk

\section{Colombia Scholarship}

Purpose: The University has partial scholarships for selffunding students from Colombia.

Eligibility: You must: 1. Be living in Colombia at the time of application. 2. Be self-funding your course. 3. Be holding an unconditional offer to study a masters course. 4. Have made your $£ 3,500$ deposit payment toward your fees

Level of Study: Postgraduate

Type: Scholarship

Value: $£ 4,000$

Country of Study: United Kingdom 
Application Procedure: The scholarships will be awarded on a first-come, first-served basis when you meet the eligibility criteria.

Additional Information: If you have discounted tuition fees from a partner university, you are not eligible for this scholarship. You do not have to hold an unconditional offer and have paid the deposit in order to apply. www.napier.ac.uk/ study-with-us/bursaries/colombia-scholarship

\section{For further information contact:}

Federica Giuntol.

Tel: $\quad$ (44)55 84214929

Email: f.giuntoli@napier.ac.uk

info@studyacrossthepond.com

\section{Data Visualisation Design, Ambiguity \& Decision Making in Megaprojects: EPSRC Studentship}

Purpose: Professor Paolo Quattrone has successfully been allocated a studentship for this project in collaboration with Costain

Eligibility: 1. United Kingdom/European Union Countries. 2. Applicants must meet EPSRC eligibility criteria. 3. Please note that international students are not eligible for this funding Level of Study: Postgraduate

Type: Studentship

Value: $£ 22,159$

Length of Study: 4 year

Frequency: Annual

Country of Study: Any country

Closing Date: 31 May

Funding: International office

\section{For further information contact:}

Email: phd@business-school.ed.ac.uk

\section{European Union Postgraduate Scholarship}

Purpose: The University has partial scholarships for selffunding students from the EU.

Eligibility: You must be: 1. Self-funding your course. 2. Be studying a full-time degree with us (students studying part-time are not eligible). 3 . holding an offer to study a masters course. 4. Domiciled and ordinarily resident in one of the following EU countries at the time of application Austria, Belgium, Bulgaria, Croatia, Cyprus, Czech Republic, Denmark, Estonia, Finland, France, Germany, Greece, Hungary, Italy, Latvia, Lithuania, Luxembourg, Malta, Netherlands, Poland, Portugal, Romania, Slovakia, Slovenia, Spain, Sweden
Level of Study: Postgraduate

Type: Scholarship

Value: $£ 7,500$

Country of Study: United Kingdom

Application Procedure: The number of scholarships is limited and they are offered on a first-come, first-served basis.

1. You meet the eligibility criteria detailed above. 2. You have made your $£ 3,500$ deposit payment towards your fees.

Additional Information: You are not eligible for this award if: 1. You are studying a full-time course lasting longer than 12 month. 2. You have discounted tuition fees from a partner university or are in receipt of another scholarship. www. napier.ac.uk/study-with-us/bursaries/european-union-postgra duate-scholarship

\section{European Union Visiting Students Scholarship}

Purpose: The University has partial scholarships for selffunding visiting students from the EU.

Eligibility: You must be: 1. Self-funding your study abroad. 2. Students must be studying full-time or a minimum of 60 credits (equal to 30 ECTS). 3. Holding an offer to study abroad for one or two trimesters. 4. Domiciled in one of the following EU countries at the time of application: Austria, Belgium, Bulgaria, Croatia, Cyprus, Czech Republic, Denmark, Estonia, Finland, France, Germany, Greece, Hungary, Italy, Latvia, Lithuania, Luxembourg, Malta, Netherlands, Poland, Portugal, Romania, Slovakia, Slovenia, Spain, Sweden.

Type: Scholarship

Value: $£ 2,000$

Length of Study: one or two trimesters

Country of Study: United Kingdom

Application Procedure: The number of scholarships is limited and they are offered on a first-come, first-served basis. You will be automatically considered for the scholarship if you meet the following selection criteria: 1 . You meet the eligibility criteria detailed above. 2. You have made your $£ 3,500$ deposit payment towards your fees.

Additional Information: You are not eligible for this award if: 1 . You have discounted tuition fees from a partner university or are in receipt of another scholarship. 2. You are coming via a partnership agreement or a study abroad provider. www. napier.ac.uk/study-with-us/bursaries/european-union-visitingstudents-scholarship

\section{Gordon David Family Scholarship}

Purpose: The Edinburgh Centre for Carbon Innovation (ECCI) is offering two scholarships for those undertaking research related to the work of ECCI 
Eligibility: 1. An eligible MSc programme (see below).

2. $\mathrm{PhD}$ in a subject related to the work of the ECCI

Level of Study: Postgraduate

Type: Scholarship

Value: $£ 8,000$

Length of Study: 3 year

Frequency: Annual

Country of Study: Any country

Closing Date: 30 April

Funding: Foundation

\section{For further information contact:}

Email: phd@business-school.ed.ac.uk

\section{GREAT India Scholarship}

Purpose: Edinburgh Napier has partnered with the British Council to offer a scholarship for a Masters students from India.

Eligibility: You must be: 1 . Domiciled in India at the time of application. 2. self-funding your course. 3 . holding an offer to study a masters course

Level of Study: Masters Degree

Type: Scholarship

Value: $£ 10,000$

Country of Study: United Kingdom

Application Procedure: The scholarship will be awarded on the basis of academic merit. View our available courses and apply online.

Additional Information: You are not eligible if: 1. you are studying a full-time course lasting longer than 12 months. 2. You have discounted tuition fees from a partner university or are in receipt of another scholarship. For more information on the GREAT Scholarships 2021, please visit the British Council's country website in your country. www.briti shcouncil.in/study-uk/scholarships/great-scholarships, www. napier.ac.uk/study-with-us/bursaries/great-india-scholarship

\section{GREAT Pakistan Scholarship}

Purpose: Edinburgh Napier has partnered with the British Council to offer a scholarship for a Masters students from Pakistan.

Eligibility: You must be: 1. Domiciled in Pakistan at the time of application. 2. Self-funding your course. 3 Holding an offer to study a masters course.

Level of Study: Masters Degree

Type: Scholarship

Value: $£ 10,000$

Country of Study: United Kingdom
Application Procedure: The scholarship will be awarded on the basis of academic merit. View our available courses and apply online.

Additional Information: You are not eligible if: 1. You are studying a full-time course lasting longer than 12 months. 2. You have discounted tuition fees from a partner university or are in receipt of another scholarship. For more information on the GREAT Scholarships 2021, please visit the British Council's country website in your country. study-uk.british council.org/scholarships/great-scholarships/pakistan, www. napier.ac.uk/study-with-us/bursaries/great-pakistan-scholarship

\section{Ian Kay Scholarships}

Purpose: The Ian Kay Scholarship Fund provides scholarships to help Chinese students to study at Edinburgh Napier University, and to help students from Edinburgh Napier University to study in China.

Eligibility: The Ian Kay Scholarship Fund provides scholarships to help Chinese students to study at Edinburgh Napier University, and to help students from Edinburgh Napier University to study in China. You must have a firm offer (conditional or unconditional) from Edinburgh Napier University to study on a course related to: 1 . Finance. 2 . Business Management. 3. International Business. You must be aged between 20 and 35 at the time of applying for your course.

Level of Study: Postgraduate

Type: Scholarship

Value: Up to $£ 10,000$ for a Chinese student and Up to $£ 5,000$ for a Scottish student

Study Establishment: Financial Services (i.e. Business Management or International Affairs); Business Management; or International Business at Edinburgh Napier University

Country of Study: China

Application Procedure: An application form is available for download. For applicants from China wishing to study in Scotland, completed application forms, including photocopies of all relevant supporting documents, should be sent to: china@napier.ac.uk

Closing Date: 30 April

Additional Information: Once a candidate has been selected for an award, the level of the Scholarship will be carefully judged bearing in mind the student's educational fees and living costs. The decision of the awarding committee is final. Applicants have no right of appeal. www.napier.ac. uk/study-with-us/bursaries/ian-kay-scholarships

\section{For further information contact:}

China Centre Room 2805, Building 3, Wanda Plaza No. 93 Jian Guo Road, Chaoyang District, 100022 Beijing, China.

Email: china@napier.ac.uk 


\section{Improving Project Delivery: ESRC Studentship}

Purpose: Professor Paolo Quattrone has successfully been allocated a studentship for the project 'Improving Project Delivery' in collaboration with the Infrastructure and Project Authority

Eligibility: 1. United Kingdom/European Union Countries. 2. Applicants must meet ESRC eligibility criteria. 3. Please note that international students are not eligible for this funding

Level of Study: Postgraduate

Type: Studentship

Value: $£ 14,777$

Length of Study: 3 year

Frequency: Annual

Country of Study: Any country

Closing Date: 31 May

Funding: International office

\section{For further information contact:}

University of Edinburgh Business School, 29 Buccleuch Place, Edinburgh EH8 9JS, United Kingdom.

Tel: $\quad$ (44) $1316515337,(44) 1316515541$

Email: paolo.quattrone@ed.ac.ukphd@business-school. ed.ac.uk

\section{Institute for Particle and Nuclear Physics MSc Prize Scholarships}

Subjects: We offer taught masters (MSc) programmes in Theoretical Physics and Mathematical Physics, and Particle \& Nuclear Physics.

Eligibility: Applicants must have applied to study full-time on the MSc Particle and Nuclear Physics programme of study.

Level of Study: Postgraduate

Type: Scholarship

Value: $£ 5,000$

Length of Study: 1 year

Frequency: Annual

Country of Study: Any country

Application Procedure: The deadline for applying for this scholarship is 1 June, details on how to apply are found on the University's Scholarships and Student Funding pages.

No. of awards offered: 6

Closing Date: 1 June

\section{For further information contact:}

Email: msc.pnp@ph.ed.ac.uk

\section{Jean Kennoway Howells Scholarship}

Purpose: One scholarship available for taught masters programmes offered by the Reid School of Music

Eligibility: The scholarship will be awarded to students who have applied for admission on a full-time basis for a postgraduate taught Masters programme of study within the Reid School of Music commencing in the academic year. To be eligible, applicants must have received an offer to study by the scholarship deadline

Level of Study: Postgraduate

Type: Scholarship

Value: $£ 15,000$

Length of Study: 1 year

Frequency: Annual

Country of Study: Any country

Closing Date: 2 March

Funding: Foundation

\section{For further information contact:}

Email: ecapgtdegrees@ed.ac.uk

\section{Lawrence Ho Scholarship}

Purpose: Established in 2009, the Lawrence Ho Scholarship and Research Fund currently provides scholarships support for students from China and Hong Kong who wish to study at Edinburgh Napier University in Scotland.

Eligibility: You must be from Hong Kong or China and have a firm offer (conditional or unconditional) from Edinburgh Napier University to study on a postgraduate course. The value of the scholarship will be based on the following undergraduate degree levels: $1 . £ 1500$, for applicants with a $2.2 \mathrm{UK}$ honour degree, lower-second class Hong Kong honour degree or $75 \%$ from a Chinese Benke degree. 2. $£ 3000$, for applicants with a 2.1 or first class UK honour degree, upper-second class or higher Hong Kong honour degree, or $80 \%+$ from a Chinese Benke degree.

Level of Study: Postgraduate

Type: Scholarship

Value: $£ 1,500$ to $£ 3,000$

Country of Study: United Kingdom

Application Procedure: The scholarships will be awarded on a first-come, first-served basis. You will be automatically considered for the scholarship and be advised of the scholarship amount you are eligible for if you meet the following selection criteria: 1 . You meet the eligibility criteria detailed above. 2. You have made your $£ 3,500$ deposit payment towards your fees.

Additional Information: www.napier.ac.uk/study-with-us/ bursaries/lawrence-ho-scholarship 


\section{Mexico Scholarship}

Purpose: The University has partial scholarships for selffunding students from Mexico.

Eligibility: You must: 1. be living in Mexico at the time of application. 2. be self-funding your course. 3 . be holding an unconditional offer to study a masters course. 4 . have made your $£ 3,500$ deposit payment toward your fees.

Level of Study: Postgraduate

Type: Scholarship

Value: $£ 4,000$

Country of Study: United Kingdom

Application Procedure: The scholarships will be awarded on a first-come, first-served basis when you meet the eligibility criteria. Apply by completing the scholarship application form available from our local representatives.

Additional Information: If you have discounted tuition fees from a partner university, you are not eligible for this scholarship. You do not have to hold an unconditional offer and have paid the deposit in order to apply. Please contact Senior International Officer for the Americas, Federica Giuntoli, if you have questions about our Mexico Scholarship. f.giuntoli@napier.ac.uk. la.studyacrossthepond. com/ www.napier.ac.uk/study-with-us/bursaries/mexico-scho larship

\section{North American Postgraduate Scholarship}

Purpose: The University has partial scholarships for selffunding students from North America.

Eligibility: Students who are from the USA and Canada who are self-funding their course are eligible for a merit-based one-time North American Postgraduate Scholarship

Level of Study: Postgraduate

Type: Scholarship

Value: $£ 2,000$

Country of Study: United Kingdom

Application Procedure: To apply for the scholarship, please email responses to the below to international@napier.ac.uk with your student ID and North American Scholarship in the subject. Please provide: 1. a 250-word response to: Why did you choose Edinburgh Napier University and your programme of study? 2. a 250-word personal statement describing: your major achievements, whether they be academic or personal, and the difference it will make to your studies at Edinburgh Napier University.

Closing Date: 25th April

Additional Information: Please note, you are not eligible for this scholarship if you are studying a full-time course lasting longer than 12 months. www.napier.ac.uk/study-with-us/bur saries/north-american-postgraduate-scholarship

\section{For further information contact:}

Email: international@napier.ac.uk

\section{Pakistan Scholarship}

Purpose: The University has partial scholarships for selffunding students from Pakistan.

Eligibility: You must be: 1. living in Pakistan at the time of application. 2. self-funding your course. 3. holding an offer to study a masters or $\mathrm{PhD}$ course. You must also achieve the following academic requirements in your most recent masters or bachelors course: Masters or Bachelor degree at $70 \%$ or above.

Level of Study: Doctorate, Masters Degree

Type: Scholarship

Value: $£ 2,000$ to $£ 3,000$

Country of Study: United Kingdom

Application Procedure: The scholarships will be awarded on a first-come, first-served basis. You will be automatically considered for the scholarship and be advised of the scholarship amount you are eligible for if you meet the following selection criteria: 1. You hold an unconditional offer to study on a full-time masters course at Edinburgh Napier. 2. You meet the eligibility criteria detailed above. 3 . You have made your $£ 3,500$ deposit payment towards your fees.

Additional Information: Students studying full-time courses lasting longer than 12 months are not eligible for this award. If you have discounted tuition fees from a partner university, you are not eligible for this scholarship. www.napier.ac.uk/ study-with-us/bursaries/pakistan-scholarship

\section{For further information contact:}

Email: international@napier.ac.uk

\section{Scotland's Saltire Scholarship}

Purpose: Edinburgh Napier has a number of scholarships for students from Canada, China, Hong Kong, India, Japan, Pakistan and the United States of America. Scotland's Saltire Scholarship is a programme of scholarships run by the Scottish Government, in partnership with Edinburgh Napier University.

Eligibility: You must: 1. have a conditional or unconditional offer to study on an eligible course at Edinburgh Napier. 2. studying a full time masters-examples of subjects that can be studied can also be found in www.scotland.org/study/ saltire-scholarships/what-can-i-study. 3. be a citizen of Canada, China, Hong Kong, India, Japan, Pakistan or the United States of America. 4. be able to demonstrate that you can meet the costs of living in Scotland and the remaining 
tuition fees. 5. not have previously studied for a full undergraduate degree in Scotland. 6. not have previously received a Saltire Scholarship. 7. meet the language requirements for the course. 8. Scholarships for Saltire programmes will continue to be available for online/distance learning.

Level of Study: Postgraduate

Type: Scholarship

Value: $£ 8,000$

Country of Study: United Kingdom

Application Procedure: Applicant must demonstrate: 1. The aspiration to work and study in a global context and take a position of leadership in their chosen career. 2. A willingness and the necessary interpersonal and communication skills required to participate in the programme of activities that accompanies the scholarships. Apply here: www.scot land.org/study/saltire-scholarships/application-form.

No. of awards offered: 50

Closing Date: 28 May

Funding: Government

Additional Information: For further information, or if you have any questions about the scheme contact Scotland's Saltire Scholarships www.scotland.org/more-info/contact-us. www.napier.ac.uk/study-with-us/bursaries/scotlands-saltirescholarship

\section{For further information contact:}

Scottish Government, St Andrew's House, Regent Road, Edinburgh EH1 3DG, United Kingdom.

Email: ScotlandsSaltireScholarships@gov.scot

\section{South Asian Scholarships at Edinburgh Napier University}

Purpose: The University has partial scholarships for self-funding students from India, Bangladesh, Nepal or Sri Lanka.

Eligibility: 1. Living in India, Bangladesh, Sri Lanka, Nepal at the time of application. 2. Self-funding your course. 3. Holding an offer to study a masters or PhD course.

Level of Study: Doctorate, Masters Degree

Type: Scholarship

Value: $£ 2,000$ to $£ 3,000$

Country of Study: United Kingdom

Application Procedure: The scholarships will be awarded on a first-come, first-served basis. You will be automatically considered for the scholarship and be advised of the scholarship amount you are eligible for if you meet the following selection criteria: 1 . You hold an unconditional offer to study on a full-time bachelors or masters course at Edinburgh Napier. 2. You meet the eligibility criteria detailed above. 3 . You have made your $£ 3,500$ deposit payment towards your fees.

Additional Information: Students studying full-time courses lasting longer than 12 months or those who study MBA (Engineering Management), MBA (Strategic Project Management) and MBA (Leadership Practice) are not eligible for this award. If you have discounted tuition fees from a partner university, you are not eligible for this scholarship. www.napier.ac.uk/study-with-us/bursaries/south-asiascholarship

\section{For further information contact:}

Tel: (44) 4042408800

Email: india@napier.ac.uk or international@napier.ac.uk

\section{Edith Cowan University}

270 Joondalup Drive, Joondalup, WA 6027, Australia.

Tel: $\quad$ (61) 863040000

Email:_enquiries@ecu.edu.au

Website: www.ecu.edu.au/

Contact: Edith Cowan University

Edith Cowan University (ECU) provides the ideal learning environment for people who want to reach their potential. Located in Western Australia, our industry-relevant teaching and research, supportive study environment and awardwinning facilities enable ECU students to do more than just survive in this world. Established in 1991, ECU took the opportunity to reshape the way higher education is delivered in a distinctive and inspiring campus environment.

\section{Brett Lockyer Scholarship}

Purpose: To enable the further development of jazz clarinet studies at ECU and to develop those specialist skills in a currently enrolled jazz clarinet student at WAAPA

Eligibility: Open for students studying jazz clarinet within the jazz programme

Level of Study: Postgraduate

Type: Scholarship

Value: Up to AU $\$ 5,000$

Application Procedure: Check website for further details. 


\section{For further information contact:}

Tel: $\quad$ (61) 893706594

Email: j.hamilton@ecu.edu.au

\section{Luke Pen Fund-Honours Scholarships}

Purpose: To encourage young people to be involved in the gaining of scientific knowledge of river characteristics

Level of Study: Graduate

Type: Scholarship

Value: AU\$50,000

Length of Study: 1 year

Frequency: Annual

Application Procedure: Check website address for further details

Closing Date: 31 March

Funding: Trusts

Contributor: Luke Pen Scholarship Trust

Additional Information: www.mediastatements.wa.gov.au/ Pages/Gallop/2004/03/The-inaugural-Luke-Pen-Scholarship. aspx

\section{For further information contact:}

Department of Water, Drainage and Waterways Branch, PO Box K822, Perth, WA 6842, Australia.

Email: james.mackintosh@water.wa.gov.au

\section{Merit International Postgraduate Scholarship}

Purpose: The Edith Cowan University is inviting applications for Merit International Postgraduate Scholarship to study in Australia. This scholarship is available to students who can demonstrate high levels of academic achievement and English competency in their previous studies

Eligibility: 1. Your programme must commence at the University of Sheffield. 2. Distance learning courses are ineligible for a merit scholarship. 3. You must receive an offer for a course studied in full at the University of Sheffield. Masters programmes split between the University of Sheffield and a partner institution are not eligible to apply for a scholarship. 4. All Crossways courses and Erasmus Mundus courses are ineligible for a merit scholarship. 5. For tuition fee purposes you must be self-funded and required to pay the overseas tuition fee. 6. You must not be a sponsored student*. 7. For scholarship purposes all March programmes are considered as postgraduate taught programmes and are not eligible for undergraduate scholarships. 8. Anyone studying a Masters/integrated $\mathrm{PhD}$ programme is eligible for a merit scholarship in the Masters element of the programme only. 9. Type: Postgraduate scholarships

Value: The scholarship offers a $10 \%$ reduction in your tuition fees for the duration of your course at ECU

Study Establishment: Scholarships are awarded to learn any of the courses offered by the university

Country of Study: Australia

Application Procedure: See the website

Closing Date: 4 May

Additional Information: For more details please visit the website scholarship-positions.com/merit-internationalpostgraduate-scholarship-edith-cowan-university-australia/ 2018/02/03/

\section{For further information contact:}

The University of Sheffield, Western Bank, Sheffield S10 2TN, United Kingdom.

Tel: (44) 1142222000

\section{Postgraduate Petroleum Engineering Scholarship}

Purpose: Petroleum Engineering has evolved into one of the well sought courses in universities. It is the field of engineering that deals with the exploration, extraction, and production of oil. It also increasingly deals with the production of natural gas. Eligibility: 1. Be commencing study of a Graduate Diploma in Petroleum Engineering (J69); Master of Engineering (Petroleum Engineering specialization) (I59); or the Master of Technology (Petroleum Engineering) (J70). 2. Meet ECU's academic direct entry requirements for the course of your choice. 3. Not be in receipt of another scholarship or sponsorship. 4. Be an International student, not an Australian Citizen, Australian Permanent Resident, or New Zealand Citizen. 5. Intend to study a postgraduate degree. 6 . Be studying at ECU Joondalup

Level of Study: Postgraduate

Type: Scholarship

Frequency: Annual

Country of Study: Any country

Closing Date: 31 July

Funding: International office

Additional Information: www.ecu.edu.au/scholarships/ details/petroleum-engineering-scholarship-undergraduate-andpostgraduate.

\section{For further information contact:}

Email: international.parternships@ecu.edu.au 


\section{Education and Research Foundation for the Society of Nuclear Medicine (SNM)}

14301 FNB Parkway, Suite 100, Omaha, NE 68154, United States of America.

\section{Tel: $\quad$ (1) 4025075125}

Email: $\quad$ theresa.pinkham@mierf.org

Website: www.mierf.org/

For over four decades ERF has supported the Society of Nuclear Medicine and Molecular Imaging (SNMMI) Grants, Awards and Scholarship program.

\section{Society of Nuclear Medicine Pilot Research Grants in Nuclear Medicine/Molecular Imaging}

Purpose: To support Master's or $\mathrm{PhD}$ students to start research in nuclear medicine

Eligibility: Open to basic and clinical scientists in early stages of their career.

Level of Study: Doctorate, Postgraduate

Type: Grant

Value: US $\$ 25,000$

Frequency: Annual

Country of Study: United States of America

Application Procedure: Applicants must submit a completed application form along with abstract of project proposal and budget proposal

No. of awards offered: 2

Closing Date: 20 February

Additional Information: www.postgraduatefunding.com/ award-669. www.postgraduatefunding.com/provider-349

For further information contact:

Email: tpinkham@erfsnm.org

\section{Education New Zealand (ENZ)}

Level 5, Lambton House, 160 Lambton Quay, Wellington 6011, New Zealand.

Tel:

(64) 44720788

Email:

info@enz.govt.nz

Website: enz.govt.nz/
ENZ is New Zealand's government agency for building international education. We promote New Zealand as a study destination and support the delivery of education services offshore.

\section{Korea New Zealand Agricultural Cooperation Scholarships (KNZACS)}

Purpose: To promote greater understanding between Korea and New Zealand, and strengthen the trade and economic relationship in veterinary or animal science or forestry sectors Level of Study: Doctorate, Postgraduate

Type: Scholarship

Value: New Zealand University fees and associated student levies for duration of study and stipend of NZ\$30,000 per year

Country of Study: New Zealand

Application Procedure: Please visit website to apply

No. of awards offered: 6

Funding: Government

Additional Information: scholarshipdb.net/scholarships-inNew-Zealand/Korea-New-Zealand-Agricultural-CooperationScholarships-Knzac-Massey-University=n0xfoMIX5hGUQg AlkGUTnw.html. enz.govt.nz/news-and-research/ed-news/ new-zealand-and-korea3a-new-opportunities/

For further information contact:

Email: christine.roberts@enz.govt.nz

\section{NZ-GRADS New Zealand Global Research Alliance Doctoral Scholarship}

Purpose: NZ-GRADS is a doctoral scholarship (PhD) scholarship offered to science students from developing countries to complete their $\mathrm{PhD}$ at a New Zealand university. The NZ-GRADS is a government-funded scholarship administered by Education New Zealand.

Eligibility: Criteria are non-negotiable: 1 . You must have an offer of place for a (direct-start) $\mathrm{PhD}$ programme at a New Zealand university (this may be conditional or non-conditional). 2. You must conduct your $\mathrm{PhD}$ study in New Zealand (not from a distance). 3. You cannot hold citizenship or permanent residency status in New Zealand or Australia. 4. You must be from a developing country: www.imf.org/external/pubs/ft/weo/2018/02/weodata/groups. $\mathrm{htm} \#$ oem. 5. Your $\mathrm{PhD}$ research topic must relate to greenhouse gas emissions from agricultural systems. 6. Your research may be hosted/facilitated by any New Zealand research organisation, however, your $\mathrm{PhD}$ programme must be organised through a New Zealand university. 
Level of Study: Postgraduate

Type: Scholarship

Value: NZ\$124,600 total value (1. New Zealand University annual tuition fees and associated student levies up to a total of NZ\$10,000 per year. 2. An annual living stipend of NZ\$28,000 per year (tax free). 3. Medical insurance cover up to NZ\$700 per year. 4. Visa application costs to a maximum of $\mathrm{NZ} \$ 1,000$. 5. Return flights to New Zealand up to a maximum of NZ\$6,000. 6. Book and thesis preparation allowance of up to NZ\$1,500)

Length of Study: 3 years

Application Procedure: To complete the application, you will need to upload the following documents: 1. Evidence of citizenship for every country for which you hold citizenship. 2. Evidence of an offer of place for a PhD programme from a New Zealand university. 3. Academic transcripts, grading scale and certificates of completion. 4. Curriculum Vitae. You will also need to provide the names and emails of two academic referees for your references.

No. of awards offered: 6

Closing Date: 1 June

Funding: Government

Additional Information: www.studyinnewzealand.govt.nz/ how-to-apply/scholarship/details?scholarshipid=138518\& institutionid $=378394$

\section{Shirtcliffe Fellowship}

Purpose: The purpose of the Shirtcliffe Fellowships is to assist students of outstanding ability and character who are graduates of a university in New Zealand, in the continuation of their studies in New Zealand or the Commonwealth.

Eligibility: Applicants must be: 1. New Zealand citizens. 2. ordinarily resident in New Zealand. 3. New Zealand university graduates. 4. planning to register or be currently registered as a doctoral candidate at a university in New Zealand or other Commonwealth country.

Level of Study: Doctorate

Type: Fellowship

Value: NZ\$5,000 per year for up to three years

Frequency: Annual

Country of Study: New Zealand

Application Procedure: The on-line application process will request and candidates must provide: 1. proof of New Zealand citizenship. 2. a statement describing their doctoral research. 3. the names and contact information of two referees. 4. a statement giving an outline of non-academic/extracurricular activities. 5. a budget of anticipated costs. Apply online: universitiesnz.communityforce.com/Login.aspx

Closing Date: 1 April

Funding: Private
Additional Information: www.universitiesnz.ac.nz/scholar ships/shirtcliffe-fellowship

\section{Education.govt.nz}

Mātauranga House, Level 1, 33 Bowen Street, Wellington 6011, New Zealand.

Tel: $\quad$ (64) 44638000

Email:_enquiries.national@education.govt.nz

Website: www.education.govt.nz/

The Ministry of Education is the Government's lead advisor on the New Zealand education system, shaping direction for sector agencies and providers. We shape an education system that delivers equitable and excellent outcomes.

\section{Ngarimu VC and 28th (Maori) Battalion Memorial Scholarships}

Purpose: These scholarships support high achieving tertiary students of Maori descent

Eligibility: 1. Applications for both scholarships will need to include a brief statement of up to 250 words, outlining the topic, the reasons for your interest in the subject area and your future expectations. 2. Preference will be given to applicants who are able to demonstrate that their studies aim to improve the social, economic and cultural wellbeing of Maori or are on Maori issues. Eligible applicants can apply for both scholarships

Level of Study: Research

Type: Scholarship

Value: Total value of up to NZ\$260,000

Frequency: Annual

Country of Study: Any country

Application Procedure: All applicants will need to include: 1. a form completed by a Kaumatua, Maori leader that certifies your whakapapa. 2. a form completed by someone who can endorse your academic achievement and suitability to study. 3. a Te Reo Maori statement that demonstrates your language capabilities. 4. a statement about the Nga Ahuatanga characteristics you possess that are similar to those identified as consistent with the 28th (Maori) Battalion soldiers

No. of awards offered: 7

Closing Date: February

Funding: Private

Additional Information: www.education.govt.nz/furthereducation/information-for-tertiary-students/scholarships/nga rimu-scholarships/ 


\section{For further information contact:}

Tel: $\quad$ (64) 800165225

Email: ngarimu.scholarship@education.govt.nz

\section{Educational Testing Service (ETS)}

660 Rosedale Road, Princeton, NJ 08541, United States of America.
Tel:
(1) 6099219000
Website: www.ets.org/

The Educational Testing Service (ETS) an independent, nonprofit organization devoted to educational research and assessment could expand opportunities for learners of all income and social status levels through more informed, objective methods for evaluation.

\section{Educational Testing Service Harold Gulliksen Psychometric Fellowship Program}

Purpose: The fellowship provides funding for promising graduate students in psychometrics, or a related field, who are conducting innovative, applied research.

Eligibility: At the time of application, candidates must be enrolled in a doctoral program, have completed all the coursework toward the doctorate, and be at the dissertation stage of their program. Dissertation topics in the areas of psychometrics, statistics, educational measurement or quantitative methods will be given priority. At the time of application, candidates will be asked to provide a statement describing any additional financial assistance such as assistantship or grant commitment that he/she will have during the fellowship period.

Level of Study: Predoctorate

Type: Fellowship

Value: US $\$ 20,000$ (stipend), US\$8,000 (tuition fees, and work-study program commitments), and a small grant to facilitate work on the fellow's research project

Frequency: As available

Country of Study: United States of America or other countries if appropriate

Application Procedure: Submit all application materials via email with PDF attachments. Two applications have to be submitted for this program. Preliminary application: 1. Letter of interest describing the research that would be undertaken during the award year and how the research fits with ETS research efforts. 2. Statement describing any additional financial assistance, such as assistantship or grant commitment, that you would have during the fellowship period. 3. Nomination letter (either as an email or as an email with a PDF attachment) from an academic advisor in support of your interest in the fellowship award. 4. Current curriculum vitae and Final Application: If your preliminary application is approved, you will be invited to submit the following materials: 1. Detailed project description (approximately 15 double-spaced pages) of the research the individual will carry out at the host university, including the purpose, goals and methods of the research. 2. Graduate academic transcripts (unofficial copies are acceptable). 3. Evidence of scholarship (presentations, manuscripts, etc.)

Closing Date: 22 January

Funding: Private

Contributor: ETS

Additional Information: Kindly refer the website for further information. www.ets.org/research/internship-fellowship/ gulliksen/

\section{For further information contact:}

Email: internfellowships@ets.org

\section{Educational Testing Service Postdoctoral Fellowships}

Purpose: To provide research opportunities to individuals who hold a doctorate in education and related fields, and to increase the number of women and minority professionals conducting research in educational measurement and related fields

Eligibility: Open to applicants who have received their doctoral degree within the past 3 years. Selections will be based on the candidate's scholarship, the technical strength of the proposed topic of research, and the explicit objective of the research and its relationship to ETS research goals and priorities

Level of Study: Postdoctorate

Type: Fellowship

Value: The amount is US\$50,000 for the 1-year period. In addition, limited relocation expenses consistent with the ETS guidelines will be reimbursed. Renewal for a second year by mutual consent

Length of Study: Up to 2 years, renewable after the first year by mutual agreement

Frequency: Annual

Country of Study: United States of America

Application Procedure: Refer the ETS website for further details. All application materials should be sent electronically as attachments

No. of awards offered: 15 
Closing Date: 1 January

Funding: Private

Contributor: ETS

For further information contact:

Email: internfellowships@ets.org

\section{Educational Testing Service Summer Internship Program in Research for Graduate Students}

Purpose: To provide research opportunities to individuals enroled in a doctoral program and to increase the number of women and underrepresented minority professionals conducting research in educational and related fields

Eligibility: Current full-time enrollment in a relevant doctoral program Completion of at least 2 years of coursework toward the $\mathrm{PhD}$ or EdD. prior to the program start date

Level of Study: Predoctorate

Type: Internship

Value: US $\$ 6,000$ salary; Transportation allowance for relocating to and from the Princeton area; Housing will be provided for interns commuting more than 50 miles

Length of Study: June to July ( 8 weeks)

Frequency: Annual

Country of Study: United States of America

Application Procedure: 1. Choose up to two research areas in which you are interested and provide written statements about your interest in the particular area(s) of research. 2. Attach a copy of your curriculum vitae (preferably as a PDF). 3. Attach a copy of your graduate transcripts (unofficial copies are acceptable). 4. Download the recommendation form and share it with your recommenders. Recommendations should come from your academic advisor and/or major professors who are familiar with your work. ETS will only accept two recommendation forms. Recommendations should be sent electronically to internfellowships@ets.org and must be received by February 1. If you would like to download the recommendation form for sending to your recommenders before submitting your application, the option to save your application information for later is available.

Closing Date: 1 February

Funding: Private

Contributor: ETS

Additional Information: Duration of Research Internship is eight weeks: 3 June-26 July

\section{For further information contact:}

Email: internfellowships@ets.org

\section{Educational Testing Service Summer Internships in Programme Direction}

Purpose: To provide opportunities, especially for women and minority professionals, for a work and learning experience that will assist the participants in exploring career alternatives in the field of measurement and evaluation

Eligibility: Current full-time enrollment in a relevant doctoral program; Completion of at least two years of coursework toward the doctorate prior to the program start date

Level of Study: Doctorate, Postgraduate

Type: Internship

Value: Salary of US $\$ 6,000$ with the transportation allowance and housing for interns who commute more than 50 miles

Length of Study: 8 weeks (3 June-26 July)

Study Establishment: ETS headquarters in Princeton

Country of Study: United States of America

Application Procedure: Application should include references and transcripts

Closing Date: 1 February

Additional Information: Applicants will be notified of selection decisions by 30 March

\section{Educational Testing Service Sylvia Taylor Johnson Minority Fellowship in Educational Measurement}

Purpose: An award to a minority scholar who has received a doctorate degree within the past ten years. The fellow will conduct independent research under the mentorship of ETS researchers. The award is for a period of up to two years, renewable after the first year by mutual agreement. Applicant must have a commitment to education, particularly educational measurement.

Eligibility: Open to applicants who have received their doctoral degree within the past 10 years and who are citizens or permanent residents of the United States. Selections will be based on the applicant's record of accomplishment, and proposed topic of research. Applicants should have a commitment to education and an independent body of scholarship that signals the promise of continuing outstanding contributions to educational measurement

Level of Study: Postdoctorate

Type: Fellowship

Value: Salary is competitive. US $\$ 5,000$ one-time relocation incentive for round-trip relocation expenses. In addition, limited relocation expenses, consistent with ETS guidelines, will be reimbursed

Length of Study: Up to 2 years, renewable after the first year by mutual agreement

Frequency: Annual

Country of Study: United States of America 
Application Procedure: Refer the ETS website for further details. All application materials should be sent electronically as attachments

No. of awards offered: 15

Closing Date: 1 February

Funding: Private

Contributor: ETS

Additional Information: Through her research, extensive writings and service to the educational community as an educator, editor, counsellor, committee member and collaborator during her lifetime, Sylvia Taylor Johnson had a significant influence in educational measurement and assessment nationally. In honour of Dr Johnson's important contributions to the field of education, the ETS has established the Sylvia Taylor Johnson Minority Fellowship in educational measurement

\section{For further information contact:}

Rosedale Road, MS-19T, Princeton, NJ 08541-0001, United States of America.
Tel:
(1) 6097341806
Fax:
(1) 6097345410
Email: internfellowships@ets.org

\section{Postdoctoral Fellowship Program}

Purpose: Individuals who have earned their doctoral degree within the last three years are invited to apply for a rewarding fellowship experience which combines working on cuttingedge ETS research projects and conducting independent research that is relevant to ETS's goals. The fellowship is carried out in the ETS offices in Princeton, N.J.

Eligibility: 1. Doctorate in a relevant discipline within the past three years. 2. Evidence of prior independent research

Level of Study: Postdoctorate

Type: Fellowship

Value: US $\$ 5,000$ one-time relocation incentive for round-trip relocation expenses

Length of Study: Up to 2 years and it is renewable

Frequency: Annual

Country of Study: Any country

Application Procedure: Two applications have to be submitted. Preliminary Application complete the electronic preliminary application form. On the application form: 1. Indicate your research area of interest. 2. Enter your statement of interest. 3. Enter an abstract about the independent research you propose to conduct while at ETS. 4 . Attach a copy of your curriculum vitae. 5 . Attach a copy of your graduate transcripts (student copy is acceptable). Final Application If your preliminary application is approved, you will be invited to submit the following materials 1. a detailed proposal (approximately five double-spaced pages) describing the research that will be carried out at ETS and how it relates to current ETS research. 2. samples of published research. 3. names and email addresses of three individuals who are familiar with your work, and who are willing to complete a recommendation form that will be sent to them electronically

Closing Date: 15 April

Funding: Private

\section{For further information contact:}

Email: internfellowships@ets.org

\section{Eidgenössische Technische Hochschule Zurich}

Patricia Heuberger-Meyer, HG E 68.1, Rämistrasse 101, CH-8092 Zürich, Switzerland.

Tel: $\quad$ (41) 446321111

Website: ethz.ch/en.html

Contact: ETH Zurich

Ever since it was founded under the name Polytechnikum back in 1855, ETH Zurich has been a national educational institution of international standing, attracting talent from all over the world.

\section{The Engineering for Development (E4D) Doctoral Scholarship Programme}

Purpose: The goal of the Engineering for Development (E4D) Programme is to promote research and education for the benefit of underprivileged people in low-income countries.

Eligibility: Only candidates with the support of an ETH professor are eligible to apply.

Level of Study: Doctorate

Type: Scholarship

Value: CHF 175,000

Frequency: As available

Country of Study: Switzerland

Application Procedure: Application Documentation comprises of: Completed Concept Note Application Form (DOCX, $38 \mathrm{~KB}$ ) (download from eth4d.ethz.ch/fundingopportunities/E4D-Scholarships/e4d-doctoral-scholarships. $\mathrm{html}$ ) along with the following compulsory annexes: 1 . CV of 
the candidate. 2. Excellent MSc degree from a recognised university and grade transcripts. 3. Support letter of the supervising professor at ETH Zurich. 4. 2 reference letters from your field of research. 5. Relevant own publications or documentation of relevant activities relating to the project. 6 . Bibliography. 7. Names and contacts of 5 independent external reviewers. Please read the Eligibility Criteria and Application Requirements (PDF, $186 \mathrm{~KB}$ ): ethz.ch/content/dam/ethz/ special-interest/dual/eth4d-dam/documents/ETH4D_Doc toral_Scholarship_Criteria_2021.pdf. Please submit your application in one single pdf to e4d@sl.ethz.ch.

Closing Date: 30 April

Funding: Foundation

Contributor: Sawiris Foundation for Social Development and Swiss Agency for Development and Cooperation

Additional Information: Applications submitted without the letter of support will not be considered. eth4d.ethz.ch/ funding-opportunities/E4D-Scholarships/e4d-doctoral-

scholarships.html

\section{For further information contact:}

Priya Mohanty, Clausiusstrasse 37, CH-8092 Zurich, Switzerland.

Email: e4d@sl.ethz.ch

\section{Electoral Commission New Zealand}

Level 6, Greenock House 39, The Terrace, PO Box 3220, Wellington 6140, New Zealand.

Tel: (64) 800367656

Email:_enquiries@elections.govt.nz

Website: vote.nz/

Electoral Commission New Zealand responsible for running New Zealand's parliamentary elections and keeping the electoral rolls up to date. We're a Crown Entity which means we work independently from government. We administer the Electoral Act 1993 which provides the rules for parliamentary elections and the electoral roll.

\section{Wallace Scholarships for Tertiary Student Research}

Purpose: To encourage research work that will be useful in designing electoral education and information programmes and help raise public awareness of electoral issues
Eligibility: Scholarships are for research as part of a New Zealand university degree

Level of Study: Research

Type: Scholarships

Value: NZ\$500-2,000

Length of Study: usually 1 year

Frequency: Annual

Country of Study: New Zealand

Application Procedure: Applicants must send a 1-page research proposal, letter of endorsement from an academic supervisor and contact details and enrollment qualifications

No. of awards offered: 6

Closing Date: 2 February

Funding: Government

\section{Embassy of France in Australia}

6 Perth Avenue, Yarralumla, Canberra, ACT 2600, Australia.

Tel: $\quad$ (61) 262160100

Email:_education@ambafrance-au.org

Website: au.ambafrance.org

The Embassy of France in Australia supports the partnership between French and Australian Universities and offers grants and scholarships to help the students' mobility.

\section{Language Assistantships in France and New Caledonia}

Purpose: To enable graduates who intend to teach French in the future or beginning teachers of French to improve their language skills

Eligibility: 1. Candidates must be Australian citizens or permanent residents. 2. Candidates must be enrolled at an Australian university or be recently graduated at the time of application. Candidates must have completed at least two years of university studies. 3. Candidates must be between 20 and 35 years of age at the time of taking up their positions (from 11 March). 4. Candidates must have a minimum Level B1 in French. 5. Candidates should preferably be single, as the salary of an assistant is not adequate to support dependents. 6 . At the time of their visa appointment, candidates will be required to submit a National Police Check dated no older than three months.

Level of Study: Graduate

Type: Assistantship

Value: Net monthly allowance: $€ 1,529$. 
Length of Study: 7 months

Frequency: Annual

Study Establishment: Any approved high school

Country of Study: Any country

Application Procedure: Application forms are available on the website of the French Embassy: www.ambafrance-au.org

No. of awards offered: 120

Closing Date: November

Funding: Government

Additional Information: These awards are organized by the higher education office of the Embassy of France in Australia. Successful applicants will conduct English conversation classes with small groups of students for 12 hours per week au.ambafrance.org/Grants-and-Opportunities-6980\#EnglishLanguage-Teaching-Assistants-Programs

\section{Ministry of Foreign Affairs (France) International Teaching Fellowships}

Purpose: To enable experienced teachers of French to spend time at a French primary school, a French college, or a French lycée

Eligibility: Open to Australian teachers of French employed by state education authorities

Level of Study: Professional development

Type: Fellowship

Length of Study: 1 year

Frequency: Annual

Study Establishment: A lycée, collège, primary school or Institut Universitaire de Formation de Maïtres (IUFM)

Country of Study: France

Application Procedure: Applicants must complete an application form, available from state departments of education and on the French Embassy website www.ambafrance-au.org

Closing Date: 30 April

Funding: Government

Additional Information: These awards are organized by the higher education office of the Embassy of France in Australia (BCF)

\section{For further information contact:}

Email: candidatures.eiffel@campusfrance.org

\section{Ministry of Foreign Affairs (France) Stage de la Réunion (One Month Scholarships)}

Purpose: To enable school teachers of French to attend a course on the methodology specific to the teaching of French at primary or secondary level

Eligibility: Open to Australian teachers of French only
Level of Study: Professional development

Type: Scholarship

Value: All costs except travel costs between Australia and Réunion Island

Length of Study: 1 month

Frequency: Annual

Study Establishment: Cifept in Le Tampon

Country of Study: Other

Application Procedure: Applicants must write for details

Closing Date: 15 March

Funding: Government

Additional Information: These awards are organised by the Bureau de Co-opération pour le Francais of the Embassy of France in Australia (BCF)

\section{For further information contact:}

Email: candidatures.eiffel@campusfrance.org

\section{SAAFE Program}

Purpose: The objective of the SAAFE program is to foster research collaborations between France and Australia in nuclear science and engineering in the field of human health, environment and nuclear fuel cycle.

Eligibility: 1. A PhD student currently enrolled in a French university or Australian AINSE-member university; OR. 2. Enrolled in a PhD in collaboration between French and Australian institutions; OR. 3. Hold a postdoctoral appointment at a French university or Australian AINSEmember university. In addition, eligible applicants must be carrying out a research project using nuclear science techniques that will stimulate research collaborations between France and Australia in the areas of Human Health Research, Environmental Research, or Nuclear Fuel Cycle Research.

Level of Study: Doctorate, Postdoctorate

Type: Scholarship

Application Procedure: Download the SAAFE application form from www.ainse.edu.au/saafe/. Please review the guidelines within the form carefully. Completed application forms, along with all supporting documentation, must be received by enquiries@ainse.edu.au

Closing Date: 30 April

Contributor: Australian Institute of Nuclear Science and Engineering Inc.

Additional Information: More information, guidelines and conditions, as well as the application form are available on the AINSE website: www.ainse.edu.au/saafe/ au.ambafrance. org/Grants-and-Opportunities-6980\#SAAFE-program-2020

\section{For further information contact:}

Email: enquiries@ainse.edu.au 


\section{Embassy of the United States in Kabul}

Humphrey Fellowship Program, Public Affairs Section, United States Embassy, Kabul, Afghanistan.

Tel: $\quad$ (93) 700108000

Website: af.usembassy.gov/embassy/kabul/

The mission of the U.S. Embassy in Kabul is to promote bilateral ties between the United States and Afghanistan. Embassy activities focus on strengthening democratic institutions, enhancing security and regional stability, fighting international terrorism, combating narcotics production and trafficking, and fostering expanded trade and investment. The U.S. Embassy's Public Affairs Section offers a wealth of information on all facets of life in the United States and also provides a forum for U.S.-Afghan cultural exchanges. The Information Resource Center (IRC) has extensive information on a variety of topics, including current and historical events and educational opportunities in the United States.

\section{Ambassadors Fund for Cultural Preservation Small Grants Competition}

Eligibility: 1. Full and complete Application for Federal Assistance (SF-424), including Budget Information for Non-Construction Programs (SF-424A), Assurances for Non-Construction Programs (SF-424B), Applicant Organizational Information Form, and, if applicable, Disclosure of Lobbying Activities (SF-LLL). 2. Project basics, including title, project dates, and AFCP focus area. 3. Project applicant information, including contact information, DUNS Number, and SAM registration status. 4. Project location. 5. Proof of official permission to undertake the project from the office, agency, or organization that either owns or is otherwise responsible for the preservation and protection of the site, object, or collection. 6. Project purpose that summarizes the project objectives and desired results. 7. Project activities description that presents the project tasks in chronological order (Note: If the proposed project is part of a larger effort involving multiple projects supported by other entities, the plan must present the full scope of the preservation effort and the place of the proposed project within that larger effort). 8. Project time frame or schedule that lists the major project phases and milestones with target dates for achieving them (Note: Applicants may propose project periods of up to 60 months [five years]; projects must begin before 30 September, and be completed no later than September 30, 2024). All submitted documents must be in English. 9. Project participant information, including resumes or $\mathrm{CVs}$ of the proposed project director and other primary project participants. For further information, refer website

Level of Study: Graduate

Type: Grant

Frequency: Annual

Country of Study: Any country

Application Procedure: The applicants will first be screened for technical eligibility based on the objectives, priorities, requirements, ineligible activities, and unallowable costs contained in this funding opportunity. The Embassy and its Washington office may deem applications ineligible if they do not fully adhere to the criteria stated

Closing Date: 28 November

Funding: Private

\section{For further information contact:}

United States Embassy New Delhi, Shantipath, Chanakyapuri, New Delhi, 110021, India.

Tel: $\quad$ (91) 1124198000

Email: Nd_GrantApplications@state.gov

\section{Hubert H. Humphrey Fellowship Program}

Purpose: The Program provides a year of professional enrichment in the United States for experienced professionals from designated countries undergoing development or political transition. The Humphrey Program is a Fulbright exchange activity. Its primary funding is provided by the U.S. Congress through the Bureau of Educational and Cultural Affairs of the U.S. Department of State.

Eligibility: 1. An undergraduate (first university or Bachelor's) degree. A candidates must have completed a university degree program requiring at least four years of full-time study to qualify for participation in U.S. graduate study programs. 2. Prospective Fellows should have a minimum of five years full-time professional experience in the relevant field and should be interested in the policy aspects of their field of specialization. 3. Limited or no prior experience in the United States. 4. Demonstrated leadership qualities. 5. Applicant should be a mid-career professionals in leadership positions who have demonstrated a commitment to public service and the potential for professional advancement. 6. English Language Ability: TOEFL Score of $71 \mathrm{iBT}$ or 6.0. - 7.0 IELTS is required but in the absence of TOEFL and IELTS at the time of submitting application, a certificate of formal English study should be provided.

Level of Study: Postdoctorate

Type: Fellowship

Length of Study: 10 month

Frequency: Annual 
Country of Study: United States of America

Application Procedure: Please submit your complete application (af.usembassy.gov/wp-content/uploads/sites/268/ Humphrey-2021-2022-Application-Form.pdf) to Kabul Humphrey Team (kabulhumphrey@state.gov)

Closing Date: 2 September

Funding: Government

Contributor: U.S. Congress through the Bureau of Educational and Cultural Affairs of the U.S. Department of State

Additional Information: af.usembassy.gov/humphreyfellowship-program/?_ga $=2.58160042 .1290610849 .161526$ 2936-1085123320.1615262936

\section{For further information contact:}

Kabul Humphrey Team, Afghanistan.

Email: kabulhumphrey@state.gov

\section{Endeavour Research Fellowship}

Canberra, ACT 2601 9880, Australia.

Email: endeavour@education.gov.au

Contact: Endeavour Research Fellowship

The Endeavour Scholarships and Fellowships are the Australian Government's competitive, merit-based scholarships and fellowships providing opportunities for Australians to undertake study, research or professional development overseas and for overseas citizens to do the same in Australia.

\section{Endeavour Research Fellowship for International Applicants}

Purpose: The Endeavour Scholarships and Fellowships aim to build Australia's reputation for excellence in the provision of education and research, support the internationalisation of the Australian higher education and research sectors and offer high-achieving individuals from overseas and Australia opportunities to increase their productivity and expertise in their field. The Endeavour Scholarships and Fellowships are the Australian Government's competitive, merit-based scholarships and fellowships providing opportunities for Australians to undertake study, research or professional development overseas and for overseas citizens to do the same in Australia.
Eligibility: Students from eligible countries can apply for the Endeavour Postgraduate Scholarship. List of Countries available in following link: scholarship-positions.com/endeavourresearch-fellowship-international-students-2014/2013/04/13/ You must: 1. apply as an Individual Endeavour Leader or Applicant Institution. 2. submit your application by the closing date, answer all mandatory questions and attach all documents as specified in the application form. 3. not be undertaking their Leadership Activity in a country where they hold citizenship/dual citizenship or permanent residency. 4. be aged 18 years or over at the commencement of their Leadership Activity. 5. not be in receipt of any other Australian Government sponsored mobility, scholarship or fellowship benefits. 6. for Postgraduate or VET Leadership Activities, be undertaking an award course under the Australian Qualifications Framework at an Australian (Home or Host) organisation.

Level of Study: Doctorate, Masters Degree, Postdoctorate, Postgraduate

Type: Fellowship

Value: All recipients will receive travel allowance AU\$3,000 (provision to pay up to AU $\$ 4,500$ under special circumstances); establishment allowance AU\$2,000 (fellowships) or AU $\$ 4,000$ (scholarships); monthly stipend AU\$3,000 (paid up to the maximum category duration on a pro-rata basis); health insurance for the full category duration (OSHC for international recipients); travel insurance (excluding during programme for international recipients); Endeavour scholarship recipients will also receive tuition fees paid up to the maximum study/research duration on a pro-rata basis. Tuition includes student service and amenities fees

Length of Study: 4-6 months

Study Establishment: Fellowships are awarded in any field of study

Country of Study: Australia

Application Procedure: Applications must be submitted using the Endeavour Online application system. To apply you must: 1. complete the online application form through EOL (for individual applicants) or ISEO (for applicant institutions) by the closing date. 2 . provide all the information requested. 3. address all eligibility criteria and assessment criteria. 4. include all necessary attachments. Before applying, you must read and understand these Program Guidelines, the application form, the FAQs, the relevant Applicant Guide and the draft Award Agreement/Leadership Activity Schedule. These documents may be found at GrantConnect at www. grants.gov.au.

Closing Date: 15 November

Funding: Government

Additional Information: For more details please visit the website: scholarship-positions.com/endeavour-researchfellowship-international-students-2014/2013/04/13/ 


\section{Engineering and Physical Sciences Research Council (EPSRC)}

Polaris House, North Star Avenue, Wiltshire, Swindon SN2 1ET, United Kingdom.

$\begin{array}{ll}\text { Tel: } & \text { (44) } 1793444120 \\ \text { Email: } & \text { grants@epsrc.ac.uk } \\ \text { Website: } & \text { epsrc.ukri.org/ }\end{array}$

The Engineering and Physical Sciences Research Council (EPSRC) is the main funding body for engineering and physical sciences research in the UK. By investing in research and postgraduate training, we are building the knowledge and skills base needed to address the scientific and technological challenges facing the nation.

\section{Daphne Jackson Fellowships}

Purpose: Daphne Jackson Fellowships are unique. They offer researchers the opportunity to return to a research career after a break of two or more years for a family, health or caring reason. By combining a personlised retraining programme with a challenging research project, held in a supportive UK university or research establishment, our Fellowships provide a vital opportunity for those looking to return to a research career.

Eligibility: The application process for a Daphne Jackson Fellowship is competitive. Individuals wishing to be considered for a Fellowship must meet the following criteria: 1. A career break of at least two years' duration, taken for family, health or caring reasons.2. A good first degree in a research subject. 3. A PhD, or at least three years research experience (academic or industrial) prior to the career break (with evidence of research impacts and outcomes). 4. UK residency status / right to remain in the UK indefinitely and based in the UK on application. 5. Good command of English (spoken and written). 6. Good computer skills. 7. Your application will be stronger if you also have post-doctoral experience and research impacts and outcomes.

Level of Study: Graduate, Postdoctorate, Research

Type: Fellowship

Value: A Daphne Jackson Fellowship covers the salary costs of the Fellow but it does not include the bench fees and consumables associated with a Fellowship.

Length of Study: 2 or 3 years

Frequency: As available

Country of Study: United Kingdom

Application Procedure: You can apply for a Daphne Jackson Fellowship in two ways: 1 . Submit an application for an advertised sponsored Fellowship where the field of research and/or the host institution may already be specified by the sponsor. The sponsor will then select their preferred candidate. You can view the opportunities currently available here: daphnejackson.org/about-fellowships/current-opportunities/ Sponsored Fellowships are also advertised on university websites and on www.jobs.ac.uk/. 2. If you know the area of research you would like to return to and/or have identified a potential host institution and/or supervisors, you can apply for a Daphne Jackson Fellowship at any time. If your application is successful, the Trust will endeavour to find suitable sponsorship. Please contact us: daphnejackson.org/contact/ to obtain further advice.

No. of awards offered: 25

Funding: Trusts

Contributor: The Daphne Jackson Trust

Additional Information: epsrc.ukri.org/funding/applicati onprocess/basics/researcherequalitydiversity/fundingequali tydiversity/ daphnejackson.org/about-fellowships/

\section{For further information contact:}

Catherine Barber, Communications Manager, The Daphne Jackson Trust, Department of Physics, University of Surrey, Guildford, Surrey GU2 7XH, United Kingdom.

\section{Tel: $\quad$ (44) 1483689166}

Email: c.barber@surrey.ac.uk; djmft@surrey.ac.uk

\section{Engineering and Physical Sciences Research Council Standard Research Studentships}

Purpose: To enable training in the methods of research Eligibility: Non European Union nationals must be settled in the United Kingdom without being subject under immigration law to any restriction for the period to which they remain. European Union nationals may apply, provided their qualifications are equivalent to a British Upper Second Class (Honours) Degree. Support will be fees only unless migrant worker status has been established

Level of Study: Postgraduate

Type: Studentship

Value: $£ 8,265$ for students in London. $£ 6,620$ for students elsewhere (1,999-2,000 rates). Values are reviewed annually. In addition, other allowances are payable under certain conditions. Approved tuition fees are paid directly to the institution

Length of Study: Maximum 3 years

Frequency: Annual

Study Establishment: Higher education institution

Country of Study: Other 
Application Procedure: Applicants must be nominated by departments of higher education institutes. Applications on behalf of students should be directed to the relevant address. Full information can be found on the web pages or from academic institutions

Closing Date: 12 July

Funding: Government

\section{Royal Society EPSRC BBSRC and Rolls Royce PLC Industry Fellowships}

Purpose: To enhance the communication on science and technology between those in industry and those in universities or similar institutions of higher education to the benefit of United Kingdom firms, higher education institutions and the individual scientist. The aim is to establish long-lasting personal and corporate linkages between the two sectors in the United Kingdom

Eligibility: Open to applicants of any nationality. Candidates should be at the mid-career level and have had significant achievement in their home organisations. Also a substantial career should be ahead of the candidate towards the end of the award, to build upon the contacts made during the fellowship. Candidates must hold a $\mathrm{PhD}$ or equivalent in their profession and a substantive post in a university or similar academic institution as a scientist, mathematician or engineer, or be employed as a scientist, mathematician or engineer in any industry, an industrial research organisation or a nationalised industry. Organisations partly or wholly supported by public funds may not act as the industrial partner for an award. Preference will be given to candidates showing evidence of previous contact with or interest in the other sector of employment

Level of Study: Postdoctorate

Type: Fellowship

Value: Payment of salary but not employers' National Insurance and pension contributions

Length of Study: Up to 2 years full-time. A part-time equivalent is available

Country of Study: Other

Application Procedure: Applicants must complete an application form available from the website. Details are available from the Royal Society Research Appointments Department Closing Date: December

Funding: Commercial, Government, Private

Additional Information: The scheme provides opportunities for academic scientists, mathematicians and engineers to work in an industrial environment and undertake a project at any stage from fundamental science to industrial innovation, and for industrial scientists, mathematicians and engineers to undertake research or course development work in an institution of higher education

\section{For further information contact:}

The Royal Society, Research Appointments Department, 6 Carlton House Terrace, London SW1Y 5AR, United Kingdom.

Tel: (44) 2074512547

Fax: (44) 2079302170

Email: e-gap@royalsoc.ac.uk

\section{Engineers Canada}

55 Metcalfe Street, Suite 300, Ottawa, ON K1P 6L5, Canada.

Tel: $\quad$ (1) 6132322474

Email: awards@engineerscanada.ca

Website: engineerscanada.ca/

Engineers Canada upholds the honour, integrity, and interests of the engineering profession by supporting consistent high standards in the regulation of engineering, encouraging the growth of the profession in Canada, and inspiring public confidence.

\section{Engineers Canada-Manulife Scholarship}

Purpose: The Manulife Scholarship program offers three scholarships to provide financial assistance to engineers returning to university for further study or research in an engineering field.

Eligibility: To be eligible for the scholarships program, candidates must be registered as an engineer (P.Eng./ing.) in good standing with one of the 12 regulators (engineerscanada.ca/ regulatory-excellence/engineering-regulators) throughout the duration of their academic year. You are a Canadian citizen or a permanent resident of Canada. Candidates must be accepted or registered for a minimum of two full-time semesters.

Level of Study: Postgraduate

Type: Scholarship

Value: $C \$ 12,500$ each

Frequency: Annual

Application Procedure: 1. You are encouraged to read the general information carefully, as only complete applications will be considered. 2. Applications can be submitted in either English or French and Engineers Canada will arrange for translation as required. 3. Submit only the required documents. 4. All questions must be clearly answered in the space provided on the webform. 5. Click the link to submit the webform: engineerscanada.ca/awards-and-honours/schol arships/application

No. of awards offered: 3 
Closing Date: 31 March

Additional Information: Applicants may only apply in one scholarship category per year. Selection of the scholarship recipients will be based only on the information provided on the application. No restrictions will be placed on scholarship recipients holding other grants or awards or receiving assistance or income from other sources. It should be noted that no individual is eligible to hold two scholarships from Engineers Canada within a competition year. Candidates must show how the degree undertaken fulfills the stated purpose of the scholarship. For more information: engineerscanada.ca/awards-andhonours/scholarships/engineers-canada-manulife-scholarship

\section{Engineers Canada's National Scholarship Program}

Purpose: To reward excellence in the Canadian engineering profession and support advanced studies and research

Eligibility: Open to citizens or permanent residents of Canada who are registered as professional engineers in good standing with a provincial/territorial engineering association/order

Level of Study: Doctorate, Graduate, MBA, Postgraduate, Research

Type: Scholarships

Value: Canadian $\mathrm{C} \$ 70,000$ in total

Frequency: Annual

Country of Study: Canada and abroad

Application Procedure: Applicants must contact Marc Bourgeois for further details

No. of awards offered: Approx. 50-55

Closing Date: 1 March

Contributor: TD Insurance Meloche-Monnex Insurance and Manulife Financial

For further information contact:

Tel: $\quad$ (1) 6132322474 ext. 238

Fax: (1) 6132305759

Email: marc.bourgeois@engineerscanada.ca

\section{English-Speaking Union (ESU)}

Dartmouth House, 37 Charles Street, London W1J 5ED, United Kingdom.

Tel:

(44) 2075291550

Email: info@dartmouthhouse.co.uk

Website: www.esu.org/

The English-Speaking Union is a charity working to give young people the speaking and listening skills and the cross-cultural understanding they need to thrive Listen, Speak, Succeed.

\section{English-Speaking Union Travelling Librarian Award}

Purpose: To encourage United States and United Kingdom contacts in the library world and establish links between pairs of libraries

Eligibility: Open to professionally qualified United Kingdom and information professionals

Level of Study: Professional development

Type: Award

Value: Up to $£ 3,000$. Board and lodging and relevant flight costs

Length of Study: A minimum of 3 weeks

Frequency: Annual

Country of Study: United States of America

Application Procedure: Candidates must submit a curriculum vitae and a covering letter explaining why they are the ideal candidates for the award

No. of awards offered: 16

Closing Date: April

Funding: Commercial, Private

Contributor: The English-Speaking Union and The Chartered Institute of Library and Information Professionals

Additional Information: Candidates should contact the Librarian by telephone or email at library@esu.org www. sla.intexta.co.uk/blg-travelling-librarian-award.php

\section{For further information contact:}

37 Charles Street, London W1J 5ED, United Kingdom.

Email: education@esu.org

\section{Entente Cordiale Scholarships}

c/o The British Library, 96 Euston Road, London NW1 2DB, United Kingdom.

Tel

$$
\text { (44) } 2074125507
$$

Email: info@francobritish.org

Website: francobritish.org/en/entente-cordiale/

Contact: Franco-British Council

The Entente Cordiale Scholarship Programme is a prestigious awards scheme that funds British postgraduate students who want to study in France. The Entente Cordiale Scholarships 
provide students with the opportunity to experience life on the other side of the channel and widen their horizons. The programme was founded in 1995 by President Jacques Chirac and Prime Minister John Major at a summit meeting. In December 2017, the Franco-British Council became the trustee of the Entente Cordiale Scholarship Trust.

\section{Bourses Scholarships}

Purpose: To allow individuals to study or carry out research in France

Eligibility: Open to British citizens

Level of Study: Postgraduate

Type: Scholarship

Value: $£ 8,000$ for students living in Paris and $£ 7,500$ for those studying outside Paris for the 1-year award, $£ 3,000$ for 3 months, $£ 6,000$ for 6 months

Length of Study: 3 months, 6 months, or 1-year

Frequency: Annual

Study Establishment: Approved universities or grande écoles

Country of Study: France

Application Procedure: Applicants must complete an application form, available from the website

No. of awards offered: 60

Closing Date: 15 March

Funding: Private

Contributor: Blue Circle (Lafarge), BP, Kingfisher PLC, EDF Energy, UBS, Xerox, Paul Minet, Sir Patrick Sheehy Schlumberger, Vodafone, Rolls Royce, Parthenon Trust

Additional Information: Scholarships are also awarded to French postgraduates to study in the United Kingdom. Interested parties should contact the British Council in Paris

\section{For further information contact:}

Email: scholarships-bourses@cbie.ca

\section{Entomological Society of Canada (ESC)}

503-386 Broadway, Winnipeg, MB R3C 3R6, Canada.

Tel: $\quad$ (1) 8888218387

Email: info@esc-sec.ca

Website: www.esc-sec.ca

Contact: Ryan Jones, Association Coordinator

Founded in Toronto on 16 April 1863, The Entomological Society of Canada was open to all students and lovers of
Entomology. The Entomological Society of Canada will be the lead organization to promote, facilitate, communicate and advocate for research and education on insects and their relatives, mentor the development of younger entomologists, and showcase Canada's entomological expertise nationally and internationally.

\section{John H. Borden Scholarship}

Subjects: Integrated Pest Management (IPM) with an entomological emphasis

Purpose: In honour of Dr. John H. Borden, and his prestigious contributions in the field of forest pest ecology, the Entomological Society of Canada is offering one postgraduate award.

Eligibility: Applicant must be a full time postgraduate student at the time of application, studying IPM at a degree granting institution in Canada.

Level of Study: Postgraduate

Type: Scholarship

Value: C\$1,000

Frequency: Annual

Country of Study: Canada

Application Procedure: Applications for Scholarships are to be submitted by email to the ESC Association Coordinator at info@esc-sec.ca. The application must contain the following documents in this order and be in a single pdf file: 1 . Cover page (1. Scholarship being applied for John H. Borden Scholarship in IPM. 2. our name and email address. 3. Email addresses of those providing letters of support.). 2. Curriculum vitae (6 pages maximum). 3. Scanned set of transcripts, either of originals, or copies certified as such by a graduate secretary/administrator or graduate supervisor, showing undergraduate and post graduate (if applicable) grades. Scan at low quality to reduce the size of the file as much as possible. Reduce size of pdf file as well. 4. A statement (1 page) of why you are studying entomology, or IPM for the Borden Scholarship. 5. A summary of your thesis research (1 page). 6. Arrange for letters of reference from your supervisor and one other person, which clearly indicate your academic abilities, communication skills, progress as a graduate student, and the novelty and scholastic contribution of your research to the field of entomology. For the John Borden Scholarship the letters should indicate the contribution of your work to IPM.

No. of awards offered: 1

Closing Date: 1 March

Additional Information: During the course of a single degree program, a student cannot receive the same scholarship more than once. esc-sec.ca/student/student-awards/ \#toggle-id-4 


\section{For further information contact:}

ESC Association Coordinator.

Email: info@esc-sec.ca

\section{Environmental Leadership Program}

P.O. BOX 907, Greenbelt, MD 20768-0907, United States of America.

Email:_info@elpnet.org

Website: elpnet.org/

The mission of the Environmental Leadership Program (ELP) is to support visionary, action-oriented, and diverse leadership for a just and sustainable future. ELP aims to catalyze change by providing emerging leaders with the support and guidance they need to launch new endeavors, achieve new successes, and rise to new leadership positions.

\section{Environmental Leadership Fellowships}

Purpose: To build the leadership capacity of the environmental field's most promising and emerging practitioners

Eligibility: Open to citizens of the United States only

Level of Study: Postgraduate

Type: Fellowship

Value: US\$750 which includes room and board for the 3 overnight retreats, participation in 10 days of training and community building and access to our network of over 480 Senior Fellows Length of Study: 2 years

Frequency: Annual

Country of Study: United States of America

Closing Date: 2 April

For further information contact:

Email:1ori@elpnet.org

\section{Environmental Protection Agency}

PO Box 3000, Johnstown Castle Estate, Wexford, Y35 W821, Ireland.

Tel:

$$
\text { (353) } 539160600
$$

Email:1info@epa.ie

Website: www.epa.ie/
The Environmental Protection Agency is at the front line of environmental protection and policing. We ensure that Ireland's environment is protected, and we monitor changes in environmental trends to detect early warning signs of neglect or deterioration. To protect and improve the environment as a valuable asset for the people of Ireland. To protect our people and the environment from harmful effects of radiation and pollution

\section{Environmental Protection Agency-IRC Scholarship Scheme}

Purpose: In partnership with the Irish Research Council, the Environmental Protection Agency (EPA) invites applications for an Environmental Protection Agency Postgraduate Scholarship, hereinafter referred to as an EPA Postgraduate Scholarship.

Eligibility: Under the EPA Co-funded Scholarships Scheme, funding is available for a small number of awards, as per the following 48-month $\mathrm{PhDs}$ (indicative budget of $€ 96,000$ ); Limited to new and innovative projects; Co-funded by an Irish host research institution on a 50/50 basis; EPA is to be consulted in the drafting of the proposed $\mathrm{PhD}$ scope, as well as in the selection process of the candidate (i.e. interview panel); All co-funded PhDs would have to adhere to the EPA's funding rules and reporting requirements

Level of Study: Postgraduate

Type: Scholarship

Value: a stipend of $€ 16,000$ per annum a contribution to fees, including non-European Union fees, up to a maximum of $€ 5,750$ per annum eligible direct research expenses of $€ 2,250$ per annum

Frequency: Annual

Country of Study: Any country

Application Procedure: All participants must create and submit their forms via the online system.

Funding: Private

Additional Information: www.epa.ie/researchandeducation/ research/epafunding/postgraduateprogrammes/ To learn more about the application process and to apply, visit the research.ie/funding/goipg/?f=postgraduate

\section{For further information contact:}

3 Shelbourne Buildings, Crampton Avenue, Ballsbridge, D04 C2Y6, Ireland.

Tel: $\quad$ (353) 12315000

Email: info@research.ie 


\section{Escola Superior d'Administració i Direcció d’Empreses (ESADE)}

Mateo Inurria, 25-27, E-28036 Madrid, Spain.

Tel: $\quad$ (34) 913597714

Email:_esade.madrid@esade.edu

Website: www.esade.edu/en

Esade is a global institution structured as a Business School, a Law School, and an Executive Education area. Esade is a global academic institution known for the quality of its education, its international outlook, and its focus on holistic personal development. Esade has strong ties to the business world. Dating back to its founding in 1958, Esade's history has been marked by a global and innovative character.

\section{Escola Superior d'Administració i Direcció d'Empreses (ESADE) MBA Scholarships}

Purpose: To help outstanding candidates access the MBA programme, Esade awards several scholarships during the admissions process.

Eligibility: Depending on the scholarship enroled students (Fellowships plus Impact); Admitted students (Direct, Merit \& Need-based Scholarships plus Excellence). Scholarships are awarded, restricted by merit achievement, geographical area, sector of activity and need based

Level of Study: MBA

Type: Scholarships

Value: Awards range from $10 \%$ to $50 \%$ of programme tuition fees, being the average award last intake $21 \%$ of tuition fees.

Length of Study: 12, 15, or 18 months

Frequency: Annual

Study Establishment: ESADE Business School

Country of Study: Spain

Application Procedure: Send all required documents for your admittance to Admission Department, complete your Scholarship Application Form (Annex 1), include supporting documents, send all required documents in PDF format to mba@esade.edu

Additional Information: www.esade.edu/mba/en/programm es/full-time-mba/fees-and-financing/full-time-mba-scholarships

\section{For further information contact:}

Avinguda d'Esplugues, 92-96, E-08034 Barcelona, Spain.

Email: esadecrm@esade.edu

\section{ESMOD Berlin}

ESMOD Berlin is the esteemed International University of Art for Fashion, which is recognized for its unique and innovative take on teaching the global fashion trade.

\section{Hessnatur Foundation Scholarship}

Purpose: Hessnatur Foundation offering Scholarships for ESMOD Berlin students to provide financial assistance for pursuing Master's Program in Sustainability in Fashion, the Hessnatur foundation is a non-profit, independent foundation conducting research and development in the field of applied sustainability, the main objective of Hessnatur Foundation covers the following charitable fields of activity.

Eligibility: 1. Candidates applying for Hessnatur Foundation Scholarship, must have applied successfully and received acceptance to the M.A. Sustainability in Fashion at ESMOD Berlin. 2. Applicants must be able to afford other expenses which include living costs and course related material costs. 3. Applicants of Hessnatur Foundation Scholarship, must possess the visas and insurances that are required to study in Germany by the start date of the course. 4. Scholarship holders are required to agree to allow ESMOD Berlin and the Hessnatur Foundation to use their images/other media and their works for educational and promotional purposes

Level of Study: Masters Degree, Postgraduate

Type: Scholarship

Study Establishment: ESMOD Berlin

Country of Study: Germany

Application Procedure: Applications must be sent via email to j.hurley@esmod.de

Closing Date: March

Additional Information: scholarship-fellowship.com/ hessnatur-foundation-scholarship/

\section{Eta Sigma Phi}

School of Arts and Humanities, Stockton University, 101 Vera King Farris Dr., Galloway, NJ 08205, United States of America.

Website: www.etasigmaphi.org/

Contact: Dr. Katherine Panagakos, Executive Secretary

Eta Sigma Phi had its beginning in 1914 when a group of students in the Department of Greek at the University of Chicago organized an undergraduate classical club to which 
honor students in Greek and Latin were elected to membership. This organization later united with a similar organization at Northwestern University and became Eta Sigma Phi. In 1924 the society became national, and chapters were organized at leading colleges and universities. Eta Sigma Phi is the national honorary collegiate society for students of Latin and/or Greek. Members are elected by local chapters which have been chartered by the society.

\section{Eta Sigma Phi Summer Scholarships}

Purpose: To enable one member of Eta Sigma Phi to attend the summer session of the American Academy in Rome, Italy, another to attend the summer session of the American School of Classical Studies in Athens, Greece and a third to attend a session of the Vergilian Society at Cumae, Italy

Eligibility: This scholarship open to members who have received a Bachelor's degree within the eight years prior to application (or shall have received it by June 1st of the current year) and who have not received a doctoral degree. For Scholarship to the American Academy in Rome, Six semester hours of credit may be earned and applied toward an advanced degree in Classics at most graduate schools, provided that arrangements have been made in advance with the graduate school. For The Vergilian Society at Cumae, members who will be rising juniors or seniors in the coming summer; preference will be given to such undergraduate students.

Level of Study: Postgraduate

Type: Scholarship

Value: Scholarship to the American Academy in Rome has a value of US\$3,575, The Brent Malcolm Froberg Scholarship to the American School of Classical Studies at Athens has a value of up to US\$3,300 (Eta Sigma Phi covers one-half of program fees and the American School remits the other half.) and The Theodore Bedrick Scholarship to the Vergilian Society at Cumae has a total value of up to US\$2,900, including the remission of one-half the tuition fee by the Vergilian Society. Only tours in Italy are covered by this scholarship

Frequency: Annual

Study Establishment: The American Academy in Rome, The American School of Classical Studies at Athens, and the Virgilian Society at Cumae

Country of Study: Other

Application Procedure: Applicants must submit a transcript of undergraduate work, letters of recommendation, and a statement not to exceed 500 words to include purpose and reasons for desiring the scholarship. For scholarship application: $\quad 32 \mathrm{cw} 1 \mathrm{q} 2 \mathrm{flwho} 2 \mathrm{fg} 8 \mathrm{v} 42 \mathrm{gqw}$ uk-wpengine.netdna-ssl. com/wp-content/uploads/2017/10/
SummerTravelScholarshipApplication.pdf. Send applications and letters of recommendation to postal address or by email mpranger@olemiss.edu

Closing Date: 15 February

Funding: Private

Additional Information: Note: In order to be valid membership must have been registered with the national office of Eta Sigma Phi by the application deadline. www.etasigmaphi.org/ summer-2021-scholarship-deadlines/

\section{For further information contact:}

Dr. Molly Pasco-Pranger, Department of Classics, P.O. Box 1848, University of Mississippi, University, MS 38677, United States of America.

Tel: $\quad$ (1) 6629157097

Email: mpranger@olemiss.edu

\section{Ethnic Minority Foundation}

Boardman House, 64 Broadway, Stratford E15 1NT, United Kingdom.

Tel: $\quad$ (44) 2084320602

Email:_enquiries@emfoundation.org.uk

Website: www.emfoundation.org.uk/

EMF is a national registered charity created in 1999; it is a social enterprise charity that uses surplus from its investment property income in London to fund its charitable activities. Our policy is to maintain reasonable salaries and overheads to maximise our capacity for public benefit.

\section{Ethnic Minority Foundation Grants}

Purpose: To provide long-term and short-term funding of minority ethnic voluntary and community organizations, and funding for other community needs such as education, health, women's and youth projects

Type: Grant

\section{For further information contact:}

Tel: $\quad$ (44) 208432 0300, Free Phone: 8006520390

Fax: (44) 2084320319 


\section{Eugène Vinaver Memorial Trust}

\author{
Email: jane.taylor@durham.ac.uk or g.n. \\ bromiley@durham.ac.uk \\ Website: www.internationalarthuriansociety.com/vinaver \\ Contact: Director, Professor Jane Taylor or Secretary, Dr \\ Geoffrey Bromiley
}

The Vinaver Trust awards grants towards the publication costs of books on Arthurian topics. It was established in 1981, when the British Branch of the International Arthurian Society, at the urging of Eugène Vinaver, formerly professor of medieval French at Manchester University, and Cedric Pickford, professor of Medieval French at the University of Hull, found the British Branch had earned an astonishingly large sum in royalties from endorsing Arthurian plates for a Swiss ceramics firm, Atelier Arts. Grants extend to any scholarly publication on an Arthurian topic, in any of the languages endorsed by the International Arthurian Society, that is German, French and English; they have covered Arthurian topics of all sorts, literary, historical, artistic, cinematic.

\section{Barron Bequest}

Subjects: Any field of Arthurian studies

Purpose: The Eugène Vinaver Trust, in association with the British Branch of the International Arthurian Society and under the terms of the Barron Bequest, offers a number of annual awards for postgraduate research in any field of Arthurian Studies.

Eligibility: The awards are open to graduates of any university in the British Isles, including those of the Republic of Ireland.

Level of Study: Postgraduate

Type: Grant

Value: $£ 1,250$, are intended as a contribution to postgraduate fees.

Frequency: Annual

Study Establishment: Any university in United Kingdom or Ireland

Country of Study: United Kingdom, Republic of Ireland Application Procedure: They may be held at any university in the British Isles, including those of the Republic of Ireland, except Owens College, University of Manchester.. For application details, please download application document form www.internationalarthuriansociety.com/british-branch/view/ awards and send the completed form as a paper copy to: Professor Jane H M Taylor.

Closing Date: 30 April

Funding: Private
Contributor: The Eugène Vinaver Memorial Trust

Additional Information: www.internationalarthuriansoci ety.com/british-branch/view/awards

\section{For further information contact:}

Professor Jane H M Taylor, Garth Head, Penruddock, Penrith, Cumbria CA11 0QU, United Kingdom.

Email: jane.taylor@durham.ac.uk

\section{European Association for the Study of Diabetes}

Rheindorfer Weg 3, D-40591 Dusseldorf, Germany.

Tel: $\quad$ (49) 2117584690

Email:_secretariat@easd.org

Website: www.easd.org/

Contact: Dr. Monika Grüsser, Managing Director

The European Association for the Study of Diabetes e.V. (EASD) is a non-profit, medical scientific association. It was founded in 1965 and its headquarters is based in Duesseldorf, Germany. The aims of the Association are to encourage and support research in the field of diabetes, the rapid diffusion of acquired knowledge and to facilitate its application.

\section{European Association for the Study of Diabetes- ADA Transatlantic Fellowships}

Purpose: To encourage research into basic or clinical questions related to diabetes and its complications

Eligibility: Applicants should have completed their MD, $\mathrm{PhD}$ or equivalent within the previous 7 years and cannot be serving an internship or residency during the fellowship. European applicants must be EASD members and United States of America applicants should be ADA members

Level of Study: Research

Type: Fellowship

Value: US $\$ 50,000$

Length of Study: 1 year

Frequency: Annual

Country of Study: United States of America

Application Procedure: Applications must be made on the forms provided. Two copies of the application forms should be submitted

Closing Date: 1 February 
Contributor: EASD-Lilly Research Fund

Additional Information: Successful applicants will be notified of the award by 1 April. Funding begins on 1 July

\section{European Calcified Tissue Society}

Rue Washington 40, B-1050 Brussels, Belgium.

Tel: (32) 476520716

Email:_ects@ectsoc.org; Roberta.mugnai@ectsoc.org

Website: www.ectsoc.org

Contact: Roberta Mugnai, Executive Director

The European Calcified Tissue Society is a volunteer-led, non-for-profit medical society and our members are basic and clinical researchers, allied health professionals who join forces to foster a multidisciplinary approach in the musculoskeletal field. ECTS can support your professional journey and membership is open to anyone working in the field at whatever stage in the career and from anywhere in the world.

\section{European Calcified Tissue Society/Servier Fellowship}

Purpose: To encourage the research involving pathophysiology of osteoporosis, particularly the coupling and uncoupling processes between bone formation and bone resorption and all related matters

Eligibility: Open for ECTS members who qualified $\mathrm{PhD} / \mathrm{MD}$ within the last 10 years. Applications to include details of a preclinical or clinical research project on the pathophysiology of osteoporosis, particularly the coupling and uncoupling processes between bone formation and bone resorption and all related matters

Level of Study: Research

Type: Fellowship

Value: $€ 80,000$

Length of Study: 2 years

Frequency: Every 2 years

Country of Study: Any country

Application Procedure: Applicants should fill an application form. For further details log on to www.ectsoc.org

No. of awards offered: 20

Closing Date: November

Funding: Commercial

Contributor: Servier

Additional Information: ectsoc.org/grants-awards-funding/ grants/ectsservier-fellowship/
For further information contact:

Email: ects@ectsoc.org

\section{European Committee for Treatment and Research in Multiple Sclerosis (ECTRIMS)}

Reinacherstrasse 131, CH-4053 Basel, Switzerland.

Tel: $\quad$ (41) 616867779

Email:_secretariat@ectrims.eu

Website: www.ectrims.eu/

Contact: ECTRIMS Secretariat

The European Committee for Treatment and Research in Multiple Sclerosis (ECTRIMS) is a non-profit organisation and an independent representative European-wide organisation devoted to MS. ECTRIMS works with researchers and clinicians of its member countries and with other organisations that share similar missions and objectives on a worldwide scale, creating networking and collaboration opportunities. The ultimate goal of ECTRIMS is to improve basic and clinical research and clinical outcomes in MS.

\section{European Committee for Treatment and Research in Multiple Sclerosis-MAGNIMS Fellowship in Magnetic Resonance Imaging in MS}

Purpose: The European MAGNIMS network (Magnetic Resonance Imaging in MS) and ECTRIMS jointly support research fellowships for young European researchers in the application of magnetic resonance studies to MS.

Eligibility: Applicants should be under 40 years and affiliated to an academic department, which can guarantee a continuation of his or her research.

Type: Fellowship

Value: $€ 55,000$

Length of Study: 1 year

Frequency: Annual

Country of Study: Any country

Application Procedure: The following documents are required: 1. Letter of intention. 2. Applicant's curriculum vitae including her/his past experience, goals for training, future career plans and publications (not to exceed 5 pages). 3. Project description. 4. Letter of acceptance from and short description of the host institution. 5. Letter of support from the home institution. 6. Acceptance of the ECTRIMS-MAGNIMS payment rules including a certification from the host institution accepting the terms of the ECTRIMS fellowship and payments. 
The necessary form is available from the online application system; the applicant should forward this form to the host institution for completion. 7. Applicant's proof of sufficient English language knowledge to ensure no language barriers with their training location, and to hold presentations, write the final report and prepare a scientific article for an international journal.

No. of awards offered: 2

Closing Date: 1 December

No. of awards given last year: 2

Additional Information: Details about all ECTRIMS Fellowship Programmes and application material can be obtained from the ECTRIMS website: www.ectrims.eu/ ectrims-magnims-fellowship-programme/ Details of the programme and the fellowship proposal process can be found on the MAGNIMS fellowships website: www.magnims.eu/fel lowships/2020-magnims-ectrims-research-fellowship-2/

\section{For further information contact:}

Prof. Christian Enzinger, Division of General Neurology, University Clinic of Neurology - Medical University of Graz, Graz, Austria.

Email: chris.enzinger@medunigraz.at

\section{European Crohn's and Colitis Organisation}

Ungargasse 6/13, A-1030 Vienna, Austria.

Tel:

Email: ecco@ecco-ibd.eu

Website: www.ecco-ibd.eu/

The European Crohn's and Colitis Organisation (ECCO), founded in 2001 to improve the care of patients with inflammatory bowel disease (IBD) in Europe, is now the largest forum for specialists in IBD in the world. It is a non-profit association, which successfully expanded from an organisation comprising 14 Country Members to an association assembling 36 member states of the Council of Europe and facilitating collaborations beyond Europe's borders. In 2009, we introduced individual membership allowing anyone around the globe interested in IBD to both benefit from our programmes and services and to join us in our mission. The ECCO Office is headquartered in Vienna, Austria, providing day-to-day support to its members and committees, and securing the seamless planning and organisation of the annual ECCO Congress and educational events.

\section{ECCO GRANT}

Purpose: ECCO Grants are designed to support IBD Research within the country of affiliation. Typically, research for ECCO Grant projects is undertaken in the home institution of the applicant. Promote innovative scientific research in IBD in Europe. Promote innovative scientific research in IBD in Europe.

Eligibility: 1. Not be older than 40 years. 2. if older than 40 years, who are within 5 years of the date of completion of their GI training or PhD graduation (a certificate needs to be provided). 3. The applicant needs to be an ECCO Member at the time of application. 4. ECCO Grants are not limited to applicants from ECCO Member countries. Applicants from non-European countries have to clearly state the impact of the proposed project on the IBD Community. 5. If your institute holds a current ECCO Grant, then another application for this period is not possible. Therefore, an institute cannot apply for two ECCO Grants in consecutive years. 6. Applicants can apply for one ECCO Award category only per annual application round. 7. Recipients that have been awarded an ECCO Grant in the past cannot reapply. 8. Submit an original research project proposal using the ECCO Fellowships and Grants Online Submission Pages.

Level of Study: Postgraduate

Type: Grant

Value: $€ 80,000$ will be awarded per ECCO Grant for 1 year Frequency: Annual

Application Procedure: Applications are to be submitted using the ECCO Fellowships and Grants Online Submission Pages: cm.ecco-ibd.eu/cmPortal/Account/Login?ReturnUrl= $\% 2$ FcmPortal $\% 2$ FPortal $\% 2$ FGEN00\%2Fnormal. Please refer: www.ecco-ibd.eu/images/5_Science/5_2_Fellowships_Grants/ 2021/2022_MASTER_ECCO\%20Grants\%20Fact\%20Sheet_ new.pdf .

No. of awards offered: 8

Closing Date: 2 August

Additional Information: www.ecco-ibd.eu/science/ fellowships-and-grants.html

\section{For further information contact:}

Email: ecco@ecco-ibd.eu

\section{European Crohn's and Colitis Organisation Fellowship}

Purpose: The European Crohn's and Colitis Organisation (ECCO) offers Research Fellowships to encourage and support young individuals in their career and promote innovative scientific research in the area of Inflammatory Bowel Diseases (IBD) in Europe. ECCO Research Fellowships aim to enhance the opportunity for IBD Trainees to work in 
European centres other than their own. Promote innovative scientific research and knowledge exchange in IBD in Europe.

Eligibility: 1 . Not be older than 40 years or still in training at the time of application. 2. Submit an original research project using the ECCO Fellowships and Grants Online Submission Pages. Incomplete applications will not be evaluated. 3. Provide a confirmation from the host institute stating that the applicant is accepted for a Fellowship, and will be under the supervision of a designated host. Both the host institute and the fellow are responsible for the successful outcome of the Fellowship. 4. At the time of the application as well as prior to the commencement of the Fellowship the candidate cannot be involved/work in any research project at the future host institute. 5. If your host institute holds a current ECCO Fellowship, then another application for this period is not possible. Therefore, an institute cannot apply for two ECCO Fellowships in consecutive years. 6 . Both the applicant and the host supervisor need to be ECCO Members at the time of application. 7. ECCO Fellowships are not limited to applicants from ECCO Member countries. Applicants from non-European countries have to clearly state the impact of the proposed project on the IBD Community. 8. Fellowships aim to enhance the opportunity for IBD Trainees to work in European centres. Exceptional circumstances such as an applicant from an ECCO Member Country travelling to a non-member country will be considered, but such an application is likely to receive a lower priority than an applicant from a member/nonmember country visiting an ECCO Member Country. 9. Applicants can apply for one ECCO Award category only per annual application round. 10. Recipients who were awarded an ECCO Fellowship in the past cannot reapply.

Type: Fellowship

Value: $€ 60,000$ will be awarded per ECCO Fellowship for 1 year

Frequency: Annual

Country of Study: Any country

Application Procedure: All applicants should submit a proposal for the research project using the ECCO Fellowships and Grants Online Submission Pages. Please refer: www.ecco-ibd.eu/images/5_Science/5_2_Fellowships_Grants/ 2021/2022 MASTER ECCO Fellowship Fact Sheet.pdf. Apply online: cm.ecco-ibd.eu/cmPortal/Account/Login? ReturnUrl $=\% 2 \mathrm{FcmPortal} \% 2 \mathrm{FPortal} \% 2 \mathrm{FGEN} 00 \% 2 \mathrm{Fnormal}$

No. of awards offered: 2

Closing Date: 2 August

Additional Information: www.ecco-ibd.eu/science/fellow ships-and-grants.html

\section{For further information contact:}

Email: ecco@ecco-ibd.eu

\section{European Molecular Biology Organization (EMBO)}

EMBO, Meyerhofstrasse 1, D-69117 Heidelberg, Germany.

Tel: $\quad$ (49) 622188910

Email: astrid.gall@embo.org; embo@embo.org

Website: www.embo.org/

Contact: Astrid Gall, Communications Officer and Writer

The European Molecular Biology Organization (EMBO) was established in 1964. EMBO stands for excellence in the life sciences. EMBO is an organization of more than 1800 leading researchers that promotes excellence in the life sciences in Europe and beyond. The major goals of the organization are to support talented researchers at all stages of their careers, stimulate the exchange of scientific information, and help build a research environment where scientists can achieve their best work.

\section{European Molecular Biology Organisation Award for Communication in the Life Sciences}

Purpose: To promote and reward public communication of the life sciences and their applications by practising scientists in Europe

Eligibility: Open to scientists working in active research in an area of life sciences at the time of nomination. Candidates must be working in Europe or Israel, and the criterion for consideration is excellence in public communication of science via any medium or activity

Type: Monetary award and medal

Value: $€ 5,000$ accompanied by a silver and gold medal inscribed with the winner's name

Frequency: Annual

Application Procedure: Applicants must apply using the forms available on the website

No. of awards offered: 27

Closing Date: 1 May

Contributor: EMBO

\section{For further information contact:}

EMBO, Meyerhofstrasse 1, Heidelberg, D-69117, Germany.

Tel: (49) 62218891119

Fax: (49) 62218891200 


\section{Long-Term Fellowship}

Purpose: The EMBO Long-Term Fellowships are awarded for a period of up to two years and support post-doctoral research visits to laboratories throughout Europe and the world. International exchange is a key feature in the application process.

Eligibility: Applicants must hold a doctorate degree or equivalent at the start of the fellowship. Applicants who already hold a $\mathrm{PhD}$ degree at the time of application are eligible to apply only if they obtained their $\mathrm{PhD}$ degree during the two years prior to the date the application is complete. Applicants must have at least one first author publication accepted in or published in an international peer reviewed journal at the time of application. All applications must involve movement between countries (detailed information about mobility requirements is listed in guidelines).

Level of Study: Postgraduate

Type: Fellowships

Value: stipend \& allowances over 2 years

Length of Study: 2 years

Frequency: Annual

Closing Date: 8 September

\section{European Science Foundation (ESF)}

1, quai Lezay-Marnésia - BP 90015, F-67080 Strasbourg, France.

Tel: (33) 388767100

Website: www.esf.org/

The European Science Foundation (ESF) is a non-governmental, internationally-oriented, non-profit association established in France in 1974. ESF is committed to promoting the highest quality science in Europe to drive progress in research and innovation. We partner with diverse institutions by leading successful projects, facilitating informed decision-making through a broad range of science support partnerships: Research Project Grant Evaluation, the coordination of European projects, funding programmes and the administration of scientific platforms.

\section{European Science Foundation Response of the Earth System to Impact Processes (IMPACT) Mobility Grants}

Purpose: To initiate longer term research projects, encourage scientific exchanges, promote international and multidisciplinary collaborations, and build strong ties between
European institutions working on impact processes and their influence on the geological and biological evolution of the earth

Eligibility: Open to young scientists, graduate students or postdoctoral researchers. Established researchers can apply but must document that they do not have access to any other form of funding for this particular project. There are no restrictions regarding citizenship but applicants must be working in a European laboratory and applying for a stay in another European country

Level of Study: Graduate, Postdoctorate

Type: Other

Country of Study: Other

Application Procedure: Applicants must submit their personal details, institutional affiliation, brief curriculum vitae, a short invitation letter from the prospective host, a few keywords summarising the research, proposed investigation (maximum two printed pages in font size 12 or $600-1,000$ words), significance of the investigation, justification of the collaborative research, and a detailed budget. One copy of the complete application must be sent to ESF and one to Dr Christian Koeberl at the University of Vienna

Contributor: The European Science Foundation

Additional Information: archives.esf.org/coordinating-rese arch/research-networking-programmes/life-earth-and-environ mental-sciences-lee/completed-esf-research-networking-prog rammes-in-life-earth-and-environmental-sciences/response-ofthe-earth-system-to-impact-processes-impact.html

\section{For further information contact:}

University of Vienna, Althanstrae 14, Vienna, A-1090, Austria.

Fax: (43) 1313367841

Email: christian.koeberl@univie.ac.at

\section{European Society of Surgical Oncology (ESSO)}

Clos Chapelle-aux-Champs, 30 - bte 1.30.30, BE-1200 Brussels, Belgium.

Tel: $\quad$ (32) 28806262

Email: carine.lecoq@essoweb.org; info@essoweb.org

Website: www.essoweb.org/

Contact: Carine Lecoq, Chief Operating Officer

The European Society of Surgical Oncology, ESSO, was established in 1981 to support it's members in advancing 
the science and practice of surgical oncology for the benefit of cancer patients. ESSO's mission is to support its members in advancing the science and practice of surgical oncology for the benefit of cancer patients. The Society aims to achieve this through a range of activities related to education, research and leadership in multidisciplinary care.

\section{European Society of Surgical Oncology Training Fellowships}

Purpose: The ESSO Education Committee offers trainees in Surgical Oncology the possibility to visit a specialist centre outside of their own country, helping them to expand their experience and learn new techniques.

Eligibility: 1. Applicants must be a specialist, trainee or junior doctor with a declared intention of specialising in a sub-specialty of surgical oncology (breast, upper GI, hepatobiliary and pancreatic, colorectal, endocrine, head and neck, thoracic, skin cancer and melanoma, gynaecology, urology, sarcoma). 2. Applicants must be ESSO members in good standing. 3. Applicants must be younger than 40 years of age or be in a training grade. 4. Both European and non-European citizens can apply. European applicants may choose to visit European or non-European units, while non-European applicants must choose to visit a European centre.

Level of Study: Postdoctorate

Type: Fellowship

Value: $€ 1.500$ for Standard training fellowships and $€ 6.000$ for Major training fellowship

Length of Study: 1 to 3 months for Standard training fellowships and 4 to 12 months for Major training fellowship

Frequency: Annual

Country of Study: Any country

Application Procedure: Applications must be submitted online (in English only) and include the following information: 1. A motivation letter describing the applicant's area of interest, research plan and reasons behind the visit. 2. A letter of support from their Head of Department. 3. A letter of invitation from the Head of the Department they wish to visit. 4. A proposal budget sheet estimating how the funds will be spent. 5. A CV including present and previous positions held (include dates from and to), relevant publications and presentations to learned societies. Applicants must submit all above documents in a single PDF document.

No. of awards offered: 9

Additional Information: Please note: Applications from non-members will not be considered. Previous Fellowship recipients will be ineligible to apply for a second award. www.essoweb.org/fellowships/training-fellowships/
For further information contact:

Adriana Pereira, Communications and Education Coordinator.

Tel: (32) 28806263

Email: adriana.pereira@essoweb.org; info@essoweb.org

\section{European Space Agency}

Email:_education@esa.int

Website: www.esa.int/

Contact: ESA HQ

The European Space Agency (ESA) is Europe's gateway to space. Its mission is to shape the development of Europe's space capability and ensure that investment in space continues to deliver benefits to the citizens of Europe and the world.

\section{European Space Agency's Postdoctoral Internal Research Fellowship Programme}

Purpose: ESA's postdoctoral Research Fellowship programme aims to offer young scientists and engineers the possibility to carry out research for two years in a variety of disciplines related to space science, space applications or space technology.

Eligibility: You must: 1. Have recently completed, or be close to completing a $\mathrm{PhD}$ in a relevant technical or scientific discipline. Preference will be given to applications submitted by candidates within five years of receiving their $\mathrm{PhD}$. 2. Be a citizen from one of the ESA Member States and European Cooperating States (www.esa.int/About_Us/Corpo rate_news/Member_States_Cooperating_States), or from Latvia and Slovenia as Associated Member States and Canada as a Cooperating State.

Level of Study: Doctorate

Type: Postdoctoral fellowship

Value: 1. A monthly remuneration (basic net salary or takehome pay) which ranges from $€ 3,000$ to $€ 3,800$ per month depending on thelocation of the ESA Establishment. 2. Comprehensive health cover under ESA's social security scheme. 3. Comprehensive health cover under ESA's social security scheme

Length of Study: 2 years

Study Establishment: Space science, Space applications and technology

Country of Study: Any country

Application Procedure: To apply for ESA Research Fellowship opportunities: 1. To see open Research Fellowships, look 
for those positions titled Internal Research Fellow among the ESA job opportunities. Candidates are selected on the basis of their application to a Research Fellowship. 2. To apply, you first have to register and create your candidate profile. Once you have applied, you will be able to track the status of your application. 3. In addition to your CV and your motivation letter, please add a proposal of up to five pages outlining your proposed research.

Additional Information: For more details please refer to the link www.esa.int/About_Us/Careers_at_ESA/Post_docs Research_Fellowship

\section{For further information contact:}

Email: contact.human.resources@esa.int

\section{European Synchrotron Radiation Facility (ESRF)}

71, avenue des Martyrs, CS 40220, F-38043 Grenoble Cedex 9, France.

Tel: $\quad$ (33) 476882757

Website: www.esrf.eu/

Contact: Gary Admans, Scientific Editor ESRF

Communication Group

In 1988, the ESRF made history as the world's first thirdgeneration synchrotron light source. The ESRF also offers research opportunities for industrial research and development. The experimental techniques available allow for testing in real time and under real operating conditions. Major companies in the fields of pharmaceuticals, chemistry, catalysis, cosmetics, food, batteries, nanotechnologies, medicine and materials use the ESRF's non-destructive techniques to improve their products and processes.

\section{European Synchrotron Radiation Facility Postdoctoral Fellowships}

Purpose: The post doctorate programme of the ESRF aims to allow young scientists from the international scientific community to acquire knowledge on the use of synchrotron radiation by participating in the running of the beamlines and in their associated research programmes.

Eligibility: $1 . \mathrm{PhD}$ in physics, biophysics, or closely related science obtained less than 3 years ago. 2. A strong background in computer programing is desirable. 3. Ability to interact with multi-disciplinary staff and facility users. 4. Proficiency in English (working language at the ESRF)
Level of Study: Postdoctorate

Type: Fellowship

Value: 1 . The annual gross salary is fixed at $€ 40,910$ for the first two years. This salary may be increased during the third year depending upon performance. 2 . In addition to the salary, the ESRF will pay a monthly expatriation allowance to new staff recruited from outside France under certain conditions of residence. For staff members recruited from outside the Grenoble area the ESRF will pay upon arrival, in one instalment, an installation allowance to contribute to installation costs. 3. Benefits include private health insurance and a supplementary pension scheme. The total contributions (for social security, pensions, health insurance and unemployment) amount to about $23 \%$ of the total remuneration (salary and allowances).

Length of Study: 2 to 3 years

Frequency: As available

Country of Study: France

Application Procedure: Applicants must complete an application form, available on www.esrf.eu

Funding: International office

Additional Information: Salary and allowances (total remuneration) are subject both to French income tax and to contributions to the French Social Security and other compulsory schemes. For more informations: www.esrf.eu/Jobs/Condi tions/PostDocs www.eurosciencejobs.com/job_display/ 194368/Postdoctoral_Fellow_for_the_Structural_Biology_ Group_ESRF_European_Synchrotron_Radiation_Facility_ Grenoble_France.

\section{For further information contact:}

Max Nanao, France.

Tel: $\quad$ (33) 476884087

Email: max.nanao@esrf.fr

\section{European Synchrotron Radiation Facility Thesis Studentships}

Subjects: Machine, Computing Services and the Experiments Division

Purpose: The ESRF supports research projects related to the use of synchrotron radiation (SR) or to synchrotron/storage ring technology. In general projects will be proposed by the ESRF.

Eligibility: Candidates must be eligible for a $\mathrm{Ph} . \mathrm{D}$. programme and have to register at a university (in one of the member or associated countries available in follwoing link: www.esrf.eu/about/organisation/members-and-associates). Special conditions apply to the first year for students based at a UK university.

Level of Study: Doctorate 
Type: Studentship

Value: The monthly gross salary will be within the range of $€ 2,286$ to $€ 2,560$ determined initially for a 2-year period and is revised for the third year. The total contribution (for social security, pensions, health insurance and unemployment) represents about $23 \%$ of the gross remuneration.

Length of Study: 2-3 years

Frequency: As available

Country of Study: France

Application Procedure: Application should contain: 1. The project title, 2. a 500 word description of the project describing its scientific basis, promise and relevance to the ESRF, 3 . the nature of the arrangement with the university, 4. the name of the supervisor at the university, 5. an estimate of the financial costs and time limit. Applicants must complete an application form, available on www.esrf.eu.

Funding: International office

Additional Information: Travel expenses are reimbursed at the beginning and at the end of the contract according to the ESRF regulations. Removal costs, however, will not be refunded. This remuneration is subject both to French income tax which depends on the individual's family situation and to contributions to the French social security and other compulsory schemes. www.esrf.eu/Jobs/Conditions/PhDStudents

\section{For further information contact:}

Evelyne JEAN-BAPTISTE, Human Resources Service, CS 40220, F-38043 Grenoble cedex 9, France.

Tel: (33) 476882019

\section{European University Institute (EUI)}

Badia Fiesolana, via dei Roccettini, 9, San Domenico di Fiesole (FI), I-50014, Italy.

Tel:

Email: mathias.neukirchen@eui.eu

Website: www.eui.eu/

Contact: Dr. Mathias Neukirchen, Director

The European University Institute (EUI) is a unique international centre for doctorate and post-doctorate studies and research, situated in the Tuscan hills overlooking Florence. Since its founding in 1972 by the six original members of the then European Communities, the EUI has earned a reputation as a leading international academic institution with a European focus. The EUI offers one of the largest doctoral and postdoctoral programmes in the social sciences in Europe.

\section{Fully Funded PhD Degree Scholarships for International Students}

Subjects: Economics, History and Civilization, Law and Political and Social Sciences

Purpose: The European University Institute is pleased to offer four-year PhD Degree Scholarships in Economics, History and Civilization, Law, and Political and Social Sciences.

Eligibility: To qualify for national funding, you must meet the specific requirements set by the national funding authorities. These may include conditions with regard to your nationality, residence, degree and its time of award. For an overview of the specific funding conditions, eligibility criteria and application instructions, please visit the information page of each relevant funding authority. You must meet the minimum degree requirements set by the relevant funding authority for admission to the EUI Ph.D. Programme. The expected level of English proficiency is level $\mathrm{C} 1$ of the Common European Framework of Reference (CEFR). Applicants are required to submit an English international language certificate to demonstrate their level.

Level of Study: Doctorate

Type: Scholarship

Value: Fully funded, 4-year Ph.D. programme (tuition fees, living expenses are covered)

Length of Study: 4 Year

Country of Study: Italy

Application Procedure: The application for admission to the EUI doctoral programme is automatically an application for national funding, with the following exceptions: Greece, Portugal, Slovenia, Spain and the United Kingdom . If you apply for funding from one of these countries, your application to the EUI can ONLY be accepted if you separately file a mandatory separate application. Please refer: www.eui.eu/ ServicesAndAdmin/AcademicService/DoctoralProgramme

No. of awards offered: 150

Closing Date: 31 January

Additional Information: www.eui.eu/en/services/academicservice/doctoral-programme

\section{For further information contact:}

Tel: (39) 554685373

Email: applyres@eui.eu

\section{Doctor of Philosophy Scholarships in the Social Sciences}

Purpose: Four-year fully-funded $\mathrm{PhD}$ programmes in History and the Social Sciences

Eligibility: To qualify for national funding, you must meet the specific requirements set by the national funding authorities. 
These may include conditions with regard to your nationality, residence, degree and its time of award. For an overview of the specific funding conditions, eligibility criteria and application instructions, please visit the information page of each relevant funding authority. You must meet the minimum degree requirements set by the relevant funding authority for admission to the EUI Ph.D. Programme. Please refer www.eui.eu/DepartmentsAndCentres/PoliticalAndSocialScie nces/DoctoralProgramme

Level of Study: Doctorate

Type: Scholarship

Value: Fully funded, 4-year Ph.D. programme (tuition fees, living expenses are covered) leading to an internationally recognised Ph.D. degree

Length of Study: Four years

Frequency: Annual

Study Establishment: European University Institute

Country of Study: Italy

Application Procedure: You must submit your application and all required documents via the interactive online application. The application for admission to the EUI doctoral programme is automatically an application for national funding, with the following exceptions: Greece, Portugal, Slovenia, Spain and the United Kingdom . If you apply for funding from one of these countries, your application to the EUI can ONLY be accepted if you separately file a mandatory separate application. For further information visit www.eui.eu/ DepartmentsAndCentres/PoliticalAndSocialSciences/Doctoral Programme

Closing Date: 31 January

Additional Information: www.eui.eu/ServicesAndAdmin/ AcademicService/DoctoralProgramme. www.eui.eu/Depar tmentsAndCentres/PoliticalAndSocialSciences/DoctoralProg ramme

\section{For further information contact:}

Via della Badia dei Roccettini, 9, I-50014 Fiesole FI, Italy.

Tel: (39) 554685373

Email: applyres@eui.eu

\section{EuroTech Universities Alliance}

Square de MeeÛs 23, 8th floor, B-1000 Brussels, Belgium.

\section{Tel: $\quad$ (32) 22740532}

Email: tatiana.panteli@eurotech-universities.eu; info@eurotech-universities.eu

Website: eurotech-universities.eu/

Contact: Tatiana Panteli, Head of Brussels Office
The EuroTech Universities Alliance is a strategic partnership of leading European universities of science and technology committed to excellence in research and education, jointly developing solutions to the grand challenges of society. The members are: 1. Technical University of Denmark (DTU), 2. École polytechnique fédérale de Lausanne (EPFL), 3. École Polytechnique (L'X), 4. Technion - Israel Institute of Technology, 5. Eindhoven University of Technology (TU/e), 6. Technical University of Munich (TUM). By promoting in-depth collaboration across research and education, as well as nurturing innovation and entrepreneurship, the Alliance combines the complementary strengths of its partner universities to jointly achieve multi-scale initiatives of high impact to society and to industry. The Alliance also openly engages with all societal actors to raise awareness on the opportunities offered by science and technology.

\section{Collaborative Offline \& Online Platform for Research EuroTechPostdoc Fellowships for International Students at European Universities}

Purpose: The EuroTechPostdoc Programme is a postdoctoral fellowship programme for young experienced researchers who have already demonstrated excellence and potential in their field of research

Eligibility: Applicants of all nationalities are eligible. Please refer the website for more details

Level of Study: Postdoctorate

Type: Postdoctoral fellowship

Value: The fellowship consists of a monthly salary for the postdoctoral researcher based on the salary scale of the host institution and is granted for a period of twenty-four (24) months maximum. Prolongation of the fellowship is not possible

Length of Study: Up to 24 months

Frequency: Annual, if funds are available

Study Establishment: Applicants may apply within one of the five focus research areas of the EuroTech Universities Alliance: Health \& Bio Engineering Smart \& Urban Mobility Data Science \& Engineering High-Performance Computing Entrepreneurship \& Innovation

Country of Study: Any country

Application Procedure: Please use the following templates for your application: 1. Project proposal template. 2. CV and publications template. 3. Ethics self-assessment

Closing Date: 28 February

Funding: Government

Contributor: European Commission This project has received funding from the European Union's Horizon research and innovation programme under the Marie Sklodowska-Curie grant agreement No 754462 
Additional Information: For more details, please browse the below website, www.scholarshipsads.com/80-coorp-eurotec hpostdoc-fellowships-international-students-european-univer sities-2018/

\section{For further information contact:}

Arcisstrasse 21, D-80333 Munich, Germany.

Tel: (49) 8928922813

Email: postdoc@eurotech-universities.eu

\section{EuroTechPostdoc}

Purpose: The EuroTech Universities Alliance is a strategic partnership of leading universities of science and technology. The EuroTechPostdoc2 programme grants fellowships to excellent experienced researchers with the objective of providing them with exceptional research and career development opportunities thanks to the joint capacity and complementary training options offered at the six universities of the EuroTech Universities Alliance.

Eligibility: There are no restrictions concerning age, gender, religion, ethnicity, sexual orientation, political views, language or nationality of the applicants. Applicants should be Experienced Researchers, and fulfill the Mobility Rule. For details, see the Rules and Regulations on postdoc2.eurotechuniversities.eu/

Level of Study: Postdoctorate

Type: A variable number of fellowships

Value: The fellowship consists of a monthly salary for the postdoctoral researcher (see details on our website) and a dedicated research budget (up to $€ 8,000$ ) and collaboration and travel budget (up to $€ 6,000$ ) related to the project.

Length of Study: 2 years

Country of Study: Other

Country of Study: Denmark, France, Germany, The Netherlands

Application Procedure: To be considered admissible, the application must be complete and submitted in the electronic submission system before the deadline of the call. For an application to be complete, it must contain the following elements: 1. Research plan (maximum five (5) pages, following the template provided). 2. Prioritized CV - including career breaks and list of all publications of the applicant, following the template provided. 3. Completed and signed ethical issues form, following the template provided. 4. Scanned copy of PhD diploma or an official statement of the awarding university that the degree has been awarded, or official statement(s) proving the four years of fulltime equivalent research experience in English. Names of intended Host Supervisor and intended Co-host Supervisor. 5. Motivation letter on carrying out a cross-border collaborative project (maximum one (1) page

No. of awards offered: 35

Closing Date: February

Funding: Foundation

Contributor: European Commission and EuroTech universities

Additional Information: Please check our online presence: postdoc2.eurotech-universities.eu/

\section{For further information contact:}

Tel: $\quad$ (31) 402474332

Email: postdoc2@eurotech-universities.eu

\section{Evangelical Lutheran Church in America (ELCA)}

8765 W Higgins Road, Chicago, IL 60631, United States of America.

Tel: $\quad$ (1) 7733802700

Website: www.elca.org/

The Evangelical Lutheran Church in America (ELCA) is one of the largest Christian denominations in the United States, with about 4 million members in nearly 10,000 congregations across the United States, Puerto Rico and the U.S. Virgin Islands. A merger of three Lutheran churches formed the ELCA in 1988. They were The American Lutheran Church, the Association of Evangelical Lutheran Churches and the Lutheran Church in America.

\section{Evangelical Lutheran Church in America Educational Grant Program}

Purpose: ELCA's Educational Grant Program (EGP) grants provides financial aids to Ph.D., Th.D., and Ed.D. candidates in heological study appropriate to seminary teaching.

Eligibility: Open to members of the Evangelical Lutheran Church in America who are enroled in an accredited graduate institution for study in a $\mathrm{PhD}, \mathrm{EdD}$, or ThD programme in a theological area appropriate to seminary teaching.

Level of Study: Doctorate

Type: Grant

Value: Grants for a total of four years of support. In addition, a fifth year of support may be awarded as a dissertation grant.

Frequency: Annual

Country of Study: United States of America 
Application Procedure: Recipients may apply annually to renew their grants for a total of four years of support. Apply online at elca.fluxx.io/user_sessions/new

\section{Closing Date: May}

Funding: Private

Additional Information: www.elca.org/grants, elca.org/ Resources/Grants\#Applicants, download.elca.org/ELCA\% 20Resource\%20Repository/ELCA_Grants_and_Scholarships Description_List.pdf?_ga $=2.62258730 .767686752 .16154406$ 50-1851674278.1615440650

\section{Evonik Foundation}

Evonik Industries AG, Rellinghauser Straße 1-11, D-45128 Essen, Germany.

Tel: $\quad$ (49) 2011773475

Email: info@evonik.com

Website: www.evonik-stiftung.de/de

Contact: Evonik Foundation

The Evonik Foundation is a nonprofit foundation based in Essen. The Evonik Foundation has a special place in Evonik's social commitment. Its motto is supporting people because it is people who shape the future. The Evonik Foundation pursues its goals through its own programs and projects and by making donations to support projects run by other organizations. The Evonik Foundation supports measures aimed, in particular, at upcoming scientists, and educational programs for socially disadvantaged children and young people.

\section{Evonik Stiftung Scholarships}

Purpose: Promoting talented young people is a top priority at the Evonik Foundation. The focus is on the Evonik Foundation scholarship for master's theses and doctorates.
Eligibility: Prerequisites for the award of a scholarship are 1. Your research project must be thematically aligned with our annual research focus or the area of Amino acid research match. 2. Your scientific research takes place in a renowned, chemical oriented working group at a German university or at a non-university research institution. 3. Your academic achievements to date are excellent. 4. The scientific training you are aiming for cannot be adequately financed by your own funds, grants from your parents or third parties.

Level of Study: Doctorate, Masters Degree

Type: Scholarship

Value: 1. Master theses: six months, $€ 250$ to $€ 600$ per month. 2. Doctorates: two years (option to extend for a maximum of one year), $€ 1,400$ per month. 3 . In addition, applications can be made to acquire specialist literature and to attend scientific conferences.

Frequency: Annual

Country of Study: Germany

Application Procedure: Details on the application process can be found in the following file, which is available as a download (pdf only in German): corporate.evonik.com/ Downloads/Evonik_Stiftung/Bewerbungsverfahren\%20Stip endium\%202021_.pdf

Closing Date: 15 February (Phase 1) and 28 February (Phase 2)

Additional Information: Please check the link for more details: www.evonik-stiftung.de/de/stipendien/stipendium-derevonik-stiftung, corporate.evonik.com/Downloads/Evonik Stiftung/Bewerbungsverfahren\%20Stipendium\%202021_.pdf

\section{For further information contact:}

Andrea Wurow, Evonik Stiftung, Rellinghauser Straße 1-11, D-45128 Essen, Germany.

Email: info@evonik-stiftung.de 